University of Nebraska - Lincoln

DigitalCommons@University of Nebraska - Lincoln

Faculty Publications in the Biological Sciences

Papers in the Biological Sciences

2011

Priority resource access mediates competitive intensity between an invasive weevil and native floral herbivores

Svata M. Louda

University of Nebraska - Lincoln, slouda1@unl.edu

Tatyana A. Rand

USDA-ARS Northern Plains Agricultural Research Laboratory, tatyana.rand@ars.usda.gov

A. A. R. Kula

University of Nebraska-Lincoln

A. E. Arnett

University of Nebraska - Lincoln

N. M. West

University of Nebraska-Lincoln, Natalie.West@ars.usda.gov

See next page for additional authors

Follow this and additional works at: https://digitalcommons.unl.edu/bioscifacpub

Part of the Life Sciences Commons

Louda, Svata M.; Rand, Tatyana A.; Kula, A. A. R.; Arnett, A. E.; West, N. M.; and Tenhumberg, Brigitte, "Priority resource access mediates competitive intensity between an invasive weevil and native floral herbivores" (2011). Faculty Publications in the Biological Sciences. 186.

https://digitalcommons.unl.edu/bioscifacpub/186

This Article is brought to you for free and open access by the Papers in the Biological Sciences at DigitalCommons@University of Nebraska - Lincoln. It has been accepted for inclusion in Faculty Publications in the Biological Sciences by an authorized administrator of DigitalCommons@University of Nebraska - Lincoln. 


\section{Authors}

Svata M. Louda, Tatyana A. Rand, A. A. R. Kula, A. E. Arnett, N. M. West, and Brigitte Tenhumberg 


\title{
Priority resource access mediates competitive intensity between an invasive weevil and native floral herbivores
}

\author{
S. M. Louda - T. A. Rand - A. A. R. Kula • \\ A. E. Arnett $\cdot$ N. M. West $\cdot$ B. Tenhumberg
}

Received: 27 December 2010/Accepted: 31 May 2011/Published online: 16 June 2011

(C) Springer Science+Business Media B.V. (outside the USA) 2011

\begin{abstract}
Mechanisms underlying invasive species impacts remain incompletely understood. We tested the hypothesis that priority resource access by an invasive biocontrol weevil, Rhinocyllus conicus, intensifies and alters the outcome of competition with native floral herbivores over flower head resources of the non-target, native host plant Cirsium
\end{abstract}

Electronic supplementary material The online version of this article (doi:10.1007/s10530-011-0036-5) contains supplementary material, which is available to authorized users.

S. M. Louda - T. A. Rand - A. A. R. Kula .

A. E. Arnett · N. M. West · B. Tenhumberg

School of Biological Sciences, University of Nebraska,

Lincoln, NE 68588, USA

\section{B. Tenhumberg}

Department of Mathematics, University of Nebraska, Lincoln, NE 68588, USA

T. A. Rand $(\bowtie)$

USDA, Agricultural Research Service, Northern Plains Agricultural Research Laboratory, 1500 North Central Ave., Sidney, MT 59270, USA

e-mail: tatyana.rand@ars.usda.gov

A. A. R. Kula

Program in Behavior, Ecology, Evolution and

Systematics, University of Maryland, College Park, MD 20742, USA

\section{A. E. Arnett}

Center for Biodiversity, Unity College, Unity, ME 04915 , USA canescens, specifically with the predominant, synchronous tephritid fly Paracantha culta. Four main results emerged. First, we documented strong, asymmetric competition, with $R$. conicus out-competing $P$. culta. Second, weevil priority access to floral resources accelerated competitive suppression of $P$. culta. Evidence for competitive suppression with increased weevil priority included decreases in both the numbers and the total biomass of native flies, plus decreases in individual $P$. culta fly mass and, so, potential fitness. Third, we found evidence for three concurrent mechanisms underlying the competitive suppression of $P$. culta by $R$. conicus. Prior use of a flower head by $R$. conicus interfered with $P$. culta pre-oviposition behavior. Once oviposition occurred, the weevil also reduced fly post-oviposition performance. Preemptive resource exploitation occurred, shown by the significant effect of flower head size on the total number of insects developing and in the magnitude of $R$. conicus effects on $P$. culta. Interference also occurred, shown by a spatial shift of surviving $P$. culta individuals away from the preferred receptacle resources as $R$. conicus priority increased. Finally, fourth, using an individual-based model (IBM), we found that the competitive interactions documented have the potential for imposing demographic consequences, causing a reduction in $P$. culta population sizes. Thus, priority resource access by an invasive insect increased competitive impact on the predominant native insect in the invaded floral guild. This study also provides the 
first experimental evidence for non-target effects of a weed biological control agent on an associated native insect herbivore.

Keywords Floral herbivores - Insect competition · Insect phenology · Invasive species · Individual based model - Demographic effects - Non-target effects of biological control $\cdot$ Biocontrol

\section{Introduction}

While studies examining the ecological consequences of insect invasions have increased over the last decade, experimental tests of the impacts of invasive insect herbivores on native populations and communities remain rare, particularly in non-forest systems (Kenis et al. 2009; Gandhi and Herms 2010). Some of the strongest case studies come from investigations of the impact of deliberately introduced biological control herbivores that have become invasive within natural ecosystems. These studies have revealed that biocontrol herbivores can have significant negative effects on native plant growth and population dynamics (Howarth 1990; Simberloff and Stiling 1996; Louda et al. 1997, 2003a, b, 2005a, b; Rose et al. 2005). However, to our knowledge, no published experiments to date have assessed the impact of such host-range expansions on the native insect herbivores associated with the new, non-target host plant. Further, relatively few studies actually identify the mechanisms underlying impacts of invasives on interacting native species, or model the potential demographic consequences of such interactions (Parker et al. 1999; Levine et al. 2003).

Identifying and quantifying the ecological factors underlying variation in the outcome and intensity of species interactions has been highlighted as a key area in need of further ecological research (Agrawal et al. 2007). Competition is one, often invoked, and potentially important mechanism by which invasive species may impact native species with whom they share resources (Levine et al. 2003). Competition is known to be an important force structuring herbivorous insect communities in general (Denno et al. 1995; Kaplan and Denno 2007), and some evidence suggests that invasive herbivores can negatively impact native insects (Kenis et al. 2009). Additionally, escape from natural enemies may confer a competitive advantage to introduced herbivores over native species (Maron and Vila 2001; Wolfe 2002). Thus, weed biocontrol agents that have moved onto native host plants may impose strong competitive effects on native insect herbivores when they share limited, discrete resources, such as fruits or seeds.

One prominent factor often mediating the intensity and outcome of competition among herbivores is relative timing of host plant resource use, the priority access effect (Denno et al. 1995). Earlier arrival to a resource may confer a competitive advantage through a variety of direct (interference) and indirect (exploitation) mechanisms. For example, priority access may allow early-arriving herbivores to distribute semiochemicals that inhibit colonization, feeding, or oviposition by later-arriving insects (Nufio and Papaj 2001), or later-arriving species may avoid plant resources that have been previously modified or damaged. Also, a later-arriving species may be excluded from higher quality resources by space pre-emption of the earlier-arriving species, an interference effect (Denno et al. 1995).

Further, even when pre-oviposition interference mechanisms are incomplete, resulting in spatial cooccurrence on a shared plant resource, the outcome of the competitive interaction can be tipped in favor of earlier-arriving species through a pre-emption of resources that creates size (developmental) or numerical advantages (Denno et al. 1995). Interference and exploitative competition are not necessarily mutually exclusive processes. Both may operate, sequentially or additively, to determine the net outcome. The role of priority resource access, as a mechanism underlying the magnitude and outcome of the competitive effects of an invasive herbivore on native herbivores, is unknown.

We evaluated the putative competitive interaction between Rhinocyllus conicus Frölich, a biological control weevil that has become invasive on flower heads of the non-target native host plant, Cirsium canescens Nutt. (Platte thistle), and the tephritid fly Paracantha culta Wiedemann, the predominant native floral herbivore on $C$. canescens. We asked: Does competition occur? If so, does priority of access to flower head resources by the invasive biocontrol weevil, $R$. conicus, influence the outcome and intensity of its interactions with $P$. culta? Given evidence of a strong interaction, what are the mechanisms underlying the negative competitive 
effects? Finally, are any demographic consequences likely for the native fly population?

\section{Methods}

Site and natural history

The experimental site was Arapaho Prairie, Arthur County, NE, a nature preserve in the Sand Hills of Nebraska, upper Great Plains, USA. The Sand Hills vegetation is a distinctive mix of tallgrass and midgrass prairie species (Kaul 1989; Keeler et al. 1980). No exotic thistle species occur at the site.

The non-target native host plant, $C$. canescens, is a characteristic thistle species of the Sand Hills prairie ecosystem (Kaul et al. 2007). It is monocarpic, growing as a rosette for 1-5 year to a threshold flowering size (Rose et al. 2005). It then flowers and sets seed, in late May to early June, dying afterward (Lamp and McCarty 1981; Louda and Potvin 1995). Seed production is reduced by the native floral feeders (Lamp and McCarty 1982b); and, flower heads with floral herbivores, especially with $R$. conicus, have few, if any viable seeds left in them (Louda et al. 1997, Louda 1998b and unpublished data). This seed loss has been shown to limit plant life-time maternal fitness (Louda and Potvin 1995) and plant density (Rose et al. 2005).

The native floral herbivores on $C$. canescens include two native picture-winged flies [Tephritidae: Paracantha culta Wiedeman, Orellia occidentale (Snow)]; a native weevil (Curculionidae: Baris nr. subsimilis Casey), and three native moths (Pyralidae: Pyrausta subsequalis subsp. plagialis Haim., Homoeosoma impressale Hulst, and $H$. ardaloniphas Goodson \& Neunzip) (Lamp and McCarty 1982a; G. Balogh, personal communication). We quantified evidence of all floral insects, but focus here on the interaction of $R$. conicus with $P$. culta, since this fly was the most common of the native internal flower head feeders (Lamp and McCarty 1982a; unpublished data). Adult $P$. culta appear on $C$. canescens in May. Males are temporarily territorial, while attempting to attract a female; fertilized females oviposit preferentially into the top of small $(10-20 \mathrm{~mm})$, immature flower heads, with or without a male present (Lamp and McCarty 1982a; personal observation). Oviposition scars are sometimes evident, but not always. The larvae feed through a floral tube and its undeveloped ovary, preferentially attaching mouth hooks into the nutritive receptacle tissues under the floret. Mature larvae pupate in position within the flower head, leaving the pupal case as evidence of successful emergence (Lamp and McCarty 1982a). Fly parasitism rates are low ( $<3 \%$ of flies in dissected flower heads over 20 years: S. Louda, unpublished data).

The invasive Eurasian flower head weevil, $R$. conicus, was first recorded on $C$. canescens in 1993 (Louda et al. 1997; Louda 1998a). This biological control weevil was introduced into North America to control exotic thistles, particularly Carduus spp. (Goeden et al. 1974; Zwölfer and Harris 1984; Gassmann and Louda 2001). However, it now occurs in the majority of $C$. canescens flower heads initiated at this site (e.g., $78.9 \%$ of all flower heads dissected in 2007). Post-oviposition occurrence and feeding by $R$. conicus significantly overlaps that of P. culta (e.g., $57.8 \%$ of all flower heads dissected in 2007: S. Louda, unpublished data). Over-wintered $R$. conicus adults emerge in May, often aggregating on plants and deposit multiple eggs onto the full range of immature flower heads available; each egg is covered by a case of masticated plant tissue (Rees 1982), making weevil oviposition relatively easy to quantify. The larvae hatch, burrow into the flower head receptacle from below, and feed on the phloemrich receptacle tissues and on the attached florets and developing ovaries and ovules. After 25-40 days, the mature larvae pupate in a distinctive chamber. The chamber remains, allowing quantification of weevil developmental success even after emergence.

Pre-oviposition fly behavior in relation to $R$. conicus oviposition priority

To quantify $P$. culta behavioral response to flower heads with versus without prior access to the heads by $R$. conicus, we ran a laboratory experiment. For each replicate $(n=20)$, we matched two flower heads by size, one collected with five $R$. conicus egg cases and one without any evidence of $R$. conicus use. Immediately upon return to the laboratory, we inserted the stem of each flower head through parafilm into a $500 \mathrm{ml}$ flask with nutrient solution. The flasks were next to each other inside the screen cage $(30 \times 30 \times$ $30 \mathrm{~cm}$ ) with a sugar-water soaked cotton ball, and held at $20-25^{\circ} \mathrm{C}$ under ambient light conditions from 
the windows. We introduced two pairs of $P$. culta per cage ( 2 females, 2 males), and recorded fly location and activity every $4 \mathrm{~h}$ (0800-2200 hours) over 8 days. We analyzed relative fly position and activity using ANOVA on arcsine-transformed proportions.

Post-oviposition test of priority access to floral resources

To test the magnitude of the interaction between $R$. conicus and P. culta and the effect of priority access on it, we did a field experiment. We found and measured the flower heads available at Arapaho Prairie 5-8 May 2000, recording evidence of any early weevil and fly oviposition, and covering each head with a mesh sleeve cage $(\sim 20 \mathrm{~cm} \times 10 \mathrm{~cm})$. After removing all heads with unambiguous evidence of early insect use from further consideration, we assigned the remaining flower heads within and between plants to one of five treatments, by first establishing blocks based on head size and position across plants (so head size was a covariate) and then randomly assigning treatments within blocks (initial $n=48-52$ heads per treatment; final $n$ by treatment in Table 1). The five treatments for $P$. culta flies were, in the order of increasing $R$. conicus weevil priority: flies only added (F0); flies added first (F1); flies and weevils added simultaneously (FW); weevils added first (W1); and, weevils only added (W0). Treatments were initiated 10-19 May 2000. This experimental design built on the results of our pilot experiment in 1999 (Online Resource 1).

Using insects caught in the field, we added two mating pairs of weevils to the mesh sleeve cages of three treatments (FW, W1, W0). Counting $R$. conicus egg cases every 1-2 days, we allowed weevils to remain in the cage until the mean number of eggs expected for a head that size were laid ( $\leq 8$ days). The eggs expected were based on field data (Louda and Arnett 2000; Louda et al. 2005b; Rand and Louda 2006, S. Louda, unpublished data); so, the time interval used allowed densities of $R$. conicus comparable to observed field densities. At the same time, we added two pairs of $P$. culta flies to the mesh sleeve cages of the first three treatments (F0, F1, FW). These flies remained in the treatment mesh sleeve cages for 6 days; missing or dead flies were replaced daily. For the two asynchronous priority treatments with both insects (F1, W1), we allowed the first species to establish (as above) before adding the second species, and then allowed them to remain for 2-8 days (as above). We kept all flower heads covered with the mesh sleeve cage during and after the manipulation, except when the flowers were in anthesis (2-3 days) to allow natural pollination. Flower heads were collected as they matured; all heads had matured or aborted by 14 July.

In the laboratory, we dissected all of the experimental flower heads, recording the number, developmental stage and condition of all insects found by species, as well as $P$. culta fly position relative to the receptacle resources. For fly position, the location of each individual $P$. culta fly was scored as: in the receptacle (deeply embedded), on the receptacle (contact, but little penetration), or above the receptacle in either the lower, or the middle, or the upper third of the volume of the matured flower head. The timing of $R$. conicus development, analyzed as proportion immature weevils in total weevils per head, did not differ significantly among treatments with weevils added (ANOVA, arcsine-transformed proportions: mean $3.6 \%, F_{3,183}=1.295, P=0.278$ ). We also recorded: individual insect mass (on an analytical scale, to $0.1 \mathrm{mg}$ ); receptacle damage type and damaged area; and, the number of filled, unconsumed seed resources remaining. We calculated the proportion of seeds eaten or damaged as: $1-[$ (number of intact seeds remaining)/(total number of seeds expected)]; the total number expected was determined from a regression of the counts of intact seed from undamaged flower heads by size and by position (data from Louda and Potvin 1995; Rose et al. 2005).

Oviposition in 2000 started early. Already by 6-8 May, at least a week earlier than usual (S. Louda, personal observation), some flower heads had either $P$. culta oviposition, evidenced by oviposition scars (often, but not always detectable), or $R$. conicus oviposition, evidenced by fresh weevil egg cases. To allow the largest sample size given the plants available, we recorded such ovipositions and assigned these flower heads to the appropriate initial treatment on 10-19 May. In the analysis, we first treated these heads as a separate sub-treatment within each treatment. The effect of natural colonization versus experimental colonization on key response variables (numbers of flies, weevils, and filled undamaged seeds) was not significant (one-way 
Table 1 Parameters $(X, \mathrm{SE})$ in the priority experiment relevant to understanding treatment response, with the treatments ordered (left to right) by increasing influence (priority) of the exotic invasive weevil, Rhinocyllus conicus; differences among treatments were evaluated using ANOVA ( $F$ test with orthogonal contrasts among treatments, $F$ ), or Kruskal-Wallis ANOVA on ranks (Tukey's HSD, $H$ ) on non-normal variables

\begin{tabular}{|c|c|c|c|c|c|c|c|c|c|c|c|c|c|c|c|c|c|}
\hline & \multicolumn{3}{|c|}{ Fly Alone (F0) } & \multicolumn{3}{|c|}{ Fly-first (F1) } & \multicolumn{3}{|c|}{ Together (FW) } & \multicolumn{3}{|c|}{ Weevil-first (W1) } & \multicolumn{3}{|c|}{$\begin{array}{l}\text { Weevil alone } \\
\text { (W0) }\end{array}$} & \multirow[t]{2}{*}{ Test } & \multirow[t]{2}{*}{$P$} \\
\hline & $N$ & $X$ & SE & $N$ & $X$ & SE & $N$ & $X$ & SE & $N$ & $X$ & SE & $N$ & $X$ & SE & & \\
\hline \multicolumn{18}{|c|}{ Initial conditions } \\
\hline $\begin{array}{l}\text { Number heads } \\
\text { per plant }\end{array}$ & 12 & 7.1 & 1.77 & 15 & 5.7 & 1.00 & 12 & 0.2 & 1.22 & 13 & 5.7 & 0.64 & 11 & 5.7 & 1.79 & $F$ & $>0.200$ \\
\hline $\begin{array}{l}\text { Stem height } \\
(\mathrm{cm})\end{array}$ & 12 & 20.8 & 3.40 & 15 & 17.1 & 4.09 & 12 & 11.5 & 3.11 & 13 & 10.7 & 1.81 & 11 & 7.9 & 2.29 & $F$ & 0.081 \\
\hline $\begin{array}{l}\text { Head width } \\
\quad(\mathrm{mm})\end{array}$ & 45 & 18.4 & 1.00 & 67 & 18.2 & 0.68 & 54 & 15.9 & 0.93 & 30 & 18.4 & 1.32 & 36 & 12.7 & 1.01 & $F$ & $<0.001$ \\
\hline $\begin{array}{l}\text { R. conicus } \\
\text { eggs }\end{array}$ & 45 & 0.0 & & 61 & 20.6 & 2.04 & 50 & 15.3 & 1.88 & 30 & 19.5 & 3.27 & 33 & 15.4 & 1.82 & $F$ & $<0.001$ \\
\hline \multicolumn{18}{|c|}{ Outcome, per head } \\
\hline $\begin{array}{l}\text { Individual } \\
\text { R. conicus } \\
\text { (mass, mg) }\end{array}$ & 45 & - & - & 7 & 5.0 & 0.18 & 53 & 5.0 & 0.21 & 30 & 5.1 & 0.21 & 36 & 5.5 & 0.26 & $F$ & 0.013 \\
\hline $\begin{array}{l}\text { Proportion } \\
\text { fly mass }\end{array}$ & 45 & 1.00 & 0.000 & 65 & 0.48 & 0.029 & 54 & 0.23 & 0.029 & 30 & 0.09 & 0.021 & 36 & 0.0 & - & $H$ & $<0.001$ \\
\hline $\begin{array}{l}\text { Individual } \\
\quad P . \text { culta } \\
\quad \text { (mass, mg) }\end{array}$ & 45 & 2.64 & 0.057 & 65 & 2.74 & 0.070 & 39 & 2.61 & 0.069 & 22 & 2.53 & 0.138 & 36 & - & - & $F$ & $<0.001$ \\
\hline $\begin{array}{r}\text { Proportion } \\
\text { damaged }\end{array}$ & 45 & 0.60 & 0.05 & 67 & 0.96 & 0.012 & 55 & 0.94 & 0.02 & 30 & 0.88 & 0.038 & 36 & 0.90 & 0.037 & $H$ & $<0.001$ \\
\hline $\begin{array}{l}\text { Final head } \\
\text { width } \\
(\mathrm{mm})\end{array}$ & 45 & 24.5 & 0.67 & 67 & 23.7 & 0.51 & 55 & 22.0 & 0.91 & 30 & 24.6 & 1.11 & 36 & 19.0 & 1.07 & $F$ & $<0.001$ \\
\hline $\begin{array}{l}\text { Seeds } \\
\text { remaining }\end{array}$ & 45 & 23.2 & 7.28 & 66 & 0.3 & 0.17 & 55 & 2.3 & 1.65 & 30 & 1.6 & 1.19 & 36 & 0.3 & 0.28 & $H$ & $<0.001$ \\
\hline
\end{tabular}

Flower heads with no insects averaged $189.0(18.8)$ filled seeds $(N=12)$

ANOVA, $P>0.10$ in all cases). Thus, we combined the data within treatment in the analysis here. Final sample size was decreased by the loss of 19 heads: nine heads on plants killed by the Plains pocket gopher (Geomys bursarius), seven heads lost to severe stem-mining and feeding damage by the early moth ( $P$. s. plagialis), and three heads disappeared. Thus, the final sample sizes of flower heads per treatment were: 45 fly-only (F0), 67 fly-first (F1), 54 simultaneous addition of fly and weevil (FW), 30 weevil-first (W1), and 36 weevil-only (W0), for a total of 232 heads.

For statistical analyses, when possible we used parametric ANOVA or ANCOVA with initial flower head size as the covariate, to evaluate the experimental outcome. In this case, significant models were followed by orthogonal contrasts to compare among specific treatments (see figures). Transformations used were: $\ln$ (numbers), square-root(counts) and arcsine(proportions). When, however, the assumptions of normality and homogeneity of variances were violated even after transformation, we used nonparametric Kruskal-Wallis ANOVA on ranks and Tukey's HSD test for multiple comparisons.

Individual based model development

To evaluate if the $R$. conicus priority effect quantified in this experiment could lead to the observed declines 
in P. culta populations (Louda and Arnett 2000), we constructed an individual based model (IBM) to predict the stochastic carrying capacity for the fly through time, both in the presence and the absence of an $R$. conicus priority effect. The model represents dynamic oviposition behavior by the fly, one mechanism that has been suggested to reduce tephritid competition effects (i.e., Headrick and Goeden 1990; Lalonde and Roitberg 1992). We assumed that the probability of a female Paracantha ovipositing in a flower head, $P_{\mathrm{E}}$, decreases with the number of eggs already present, and that this probability can be modeled with the following sigmoidal function:

$P_{\mathrm{E}}=\exp \left(-(E / \eta)^{\beta}\right)$,

where $E$ represents the number of eggs already present in the flower head, $\eta$ denotes the scale parameter, and $\beta$ denotes the $E$-dependent shape parameter. Note, $\eta$ and $\beta$ together specify the strength of oviposition avoidance (see Figures I and II of OnLine Resource 2). Oviposition probability was equal to one when zero larvae were in a flower head, followed by a decreasing probability of fly oviposition with increasing number of larvae in a flower head until the probability asymptotes to zero. We chose values for $\eta$ and $\beta$ that would result in number of flies per flower head that was within the range of naturally occurring flower head infestations (field data: $0-0.8$ flies per head, simulations: $0-0.24$ flies per head). The range in fly infestation is expected to vary more in the field because head sizes vary in the field but are identical sizes in the simulations.

The model assumes that at the beginning of each annual generation of flies, there were 20 flower heads available per unit area of prairie, which is a likely density in the typical thistle patch (unpublished field data). We started the model with 10 female flies per unit area. We assumed each female fly emerged with 100 eggs, and could visit 10 flower heads before she died (10 oviposition opportunities), including potential return visits to an already visited flower head. At the start of the simulation, the first fly randomly chose a flower head and oviposited a clutch of eggs, with probability $P_{\mathrm{E}}$. Fly clutch size was drawn from a truncated Poisson distribution and varied between one and five eggs, consistent with empirical observations (Lamp and McCarty 1982a, b). The model then updated the egg load of the fly and the number of eggs in the flower head. Over time, the egg load of the fly declined and the numbers of eggs in the flower heads increased. The model sequentially provided all flies with 10 opportunities to oviposit a clutch of eggs. Then the model counted the number of eggs in all flower heads to determine the population size of the next generation. In our model, we assumed all eggs survived to become adult flies; model predictions did not change even if only a fraction of the eggs survived (unpublished data). We simulated fly populations for 10 consecutive generations; however, after only 2-3 generations the fly population stabilized and fluctuated around the stochastic carrying capacity, $K_{\mathrm{s}}$. We ran the model 100 times for 10 generations and calculated the average value for $K_{\mathrm{s}}$. Note, $K_{\mathrm{s}}$ specifies the average number of flies that, in the long run, can be sustained by the resources available ( $N=20$ flower heads in the model). The predicted $K_{\mathrm{s}}$ was not influenced by the initial egg load of female flies (Figure III, On-Line Resource 2) and only slightly increased with the number of oviposition opportunities (Figure IV, On-Line Resource 2).

In the simulations with the weevil priority effect, we randomly distributed $R$. conicus eggs among the flower heads before each new fly generation emerged. We assumed that each early oviposited $R$. conicus larva consumed more resources than a fly larva. If the priority strength was 9 , each $R$. conicus egg had the same deterrent effect on fly oviposition probability as nine fly larvae (Eq. 1: one fly egg + one $R$. conicus egg $\rightarrow P_{\mathrm{E}=10}=0.37$ ). In our simulations we explored the effect of priority strength, the proportion of heads infested with weevil eggs, and resource availability (number of flower heads) on the average stochastic carrying capacity $K_{\mathrm{s}}$.

\section{Results}

Pre-oviposition fly behavior in relation to prior weevil oviposition

In the laboratory test of fly behavior, while native $P$. culta used heads with and without prior weevil exposure, it clearly preferred both plants and flower heads without prior oviposition by $R$. conicus. More $P$. culta occurred on plants without egg cases deposited by $R$. conicus in prior access $(51.6 \%$, SE 
2.96) than on plants with $R$. conicus egg cases (39.3\%, SE 2.65) (ANOVA on arcsine-transformed proportions: $F_{1,57}=9.59, P=0.003$ ). Further, more $P$. culta females observed probing flower heads for oviposition were on heads without $R$. conicus egg cases $(44.4 \%$, SE 2.87) than with $R$. conicus egg cases $(27.5 \%$, SE 3.41) (ANOVA, arcsine-transformed proportions: $F_{1,57}=14.376, \quad P<0.001$ ). Thus, we found that prior exposure to and use of a plant or flower head by $R$. conicus interfered to some degree with the pre-oviposition behavior of $P$. culta, reducing the acceptability of the flower head resources to the native fly.

Post-oviposition response to priority floral resource access in the field

\section{Total numerical response}

In the field experiment, the total number of insects developing per flower head varied significantly among treatments (Fig. 1a; $P<0.001$ ), consistent with the results of our initial, smaller-scale experiment the previous year (Online Resource 1). The total number of insects was highest in the fly-first (F1) treatment, intermediate in three treatments-fly-only (F0), simultaneous (FW) and weevil-first (W1) - and lowest in the weevil-only (W0) treatment (Orthogonal contrasts, all $P<0.002$ ). More insects occurred in the fly-first (F1) treatment than any of the other three treatments with weevils added (Fig. 1a). The total number of insects that developed decreased as $R$. conicus priority increased (Fig. 1a). Flower head size, a measure of floral resource availability, was a significant covariate in explaining the total number of insects that developed per flower head within treatment $\left(F_{1,226}=83.862, P<0.001\right)$. Thus, when the two insects co-occurred, priority access by $P$. culta allowed more total insects to be packed onto the floral resources, whereas priority access by $R$. conicus led to fewer total insects developing on the flower head resources.

\section{Total biomass response}

Since insect sizes vary, we also asked how total insect biomass changed in response to increased weevil priority. Total insect biomass per flower head (Fig. 1b) showed the same pattern as total insect numbers (Fig. 1a) (ANCOVA, square-root transformed flower head diameter as covariate, on square-root transformed biomass, $P<0.001)$. Insect biomass per flower head was higher in the fly-first (F1) treatment, when $R$. conicus was added after a week delay, than in the other treatments $(124.2 \mathrm{mg}$ vs. $38.0-76.1 \mathrm{mg}$; orthogonal contrasts, all $P<$ 0.001), again consistent with the results of the preliminary experiment (Online Resource 1: Results). Flower head diameter also helped explain the total biomass of insects per flower head within treatment $\left(F_{1,226}=99.537, P<0.001\right)$. Thus, when the two insects co-occurred, total insect biomass decreased as $R$. conicus priority on floral resources increased.

\section{Weevil numerical response}

As planned, more $R$. conicus developed in the four treatments with weevils than in the fly-only treatment, where $R$. conicus densities were near zero, indicating a successful execution of the treatment (Fig. 1c; ANOVA, $P<0.001, R^{2}=0.708$ ). No significant differences in number of weevils per head occurred among the four treatments with weevils added (Fig. 1c; orthogonal contrasts, all $P>0.20$ ), although the number trended toward being higher in the weevil-first (W1) treatment (Fig. 1c). Finally, flower head size, representing floral resource availability, again was a significant covariate, helping explain variation in the number of $R$. conicus that developed per flower head within treatment $\left(F_{1,226}=49.148, P<0.001\right)$. Overall, these results suggest a carrying capacity of $\sim 10-13 R$. conicus per Platte thistle flower head, and no significant effect of co-occurring $P$. culta on weevil numbers.

\section{Weevil biomass response}

The total biomass of $R$. conicus per flower head (Fig. 1d) was higher in the weevil-first (W1) treatment than in the other treatments with weevils added (Tukey's HSD, $P=0.025$ ). Exclusive $R$. conicus access (W0 treatment) led to the largest weevils (5.8 mg per weevil vs. $4.9-5.0 \mathrm{mg}$ in the other three treatments with weevils added); individual $R$. conicus size (mass) was significantly greater in the weevilonly (W0) treatment than in the other weevil added treatments (ANCOVA treatment main effect, $\left.F_{3,181}=3.665, P=0.013\right)$. Flower head size was 

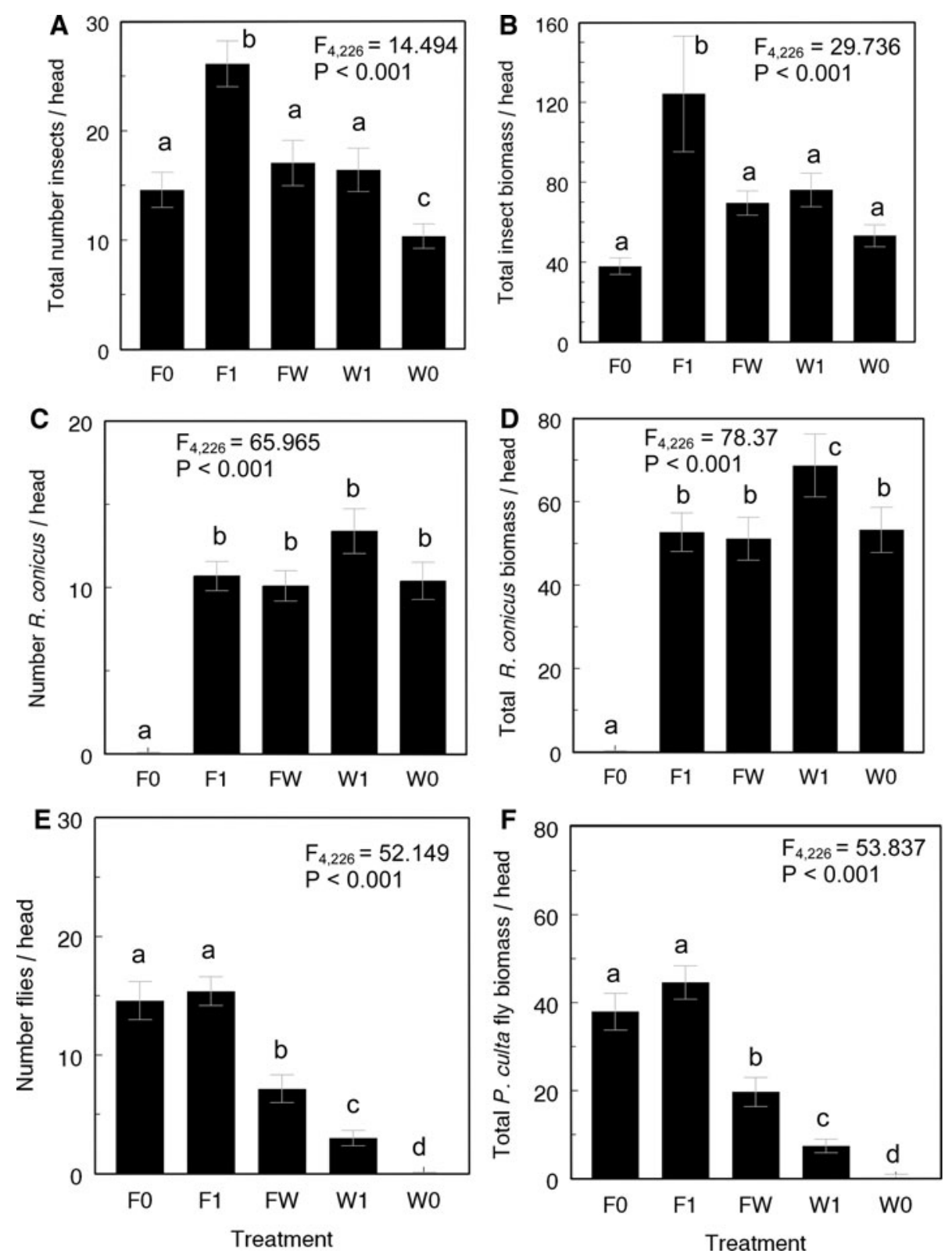

Fig. 1 Number and biomass of insects per flower head overall and by species in the field priority access experiment (least squares mean, SE), by treatment: a total number of insects; b total mass of insects; $\mathbf{c}$ number Rhinocyllus conicus; $\mathbf{d}$ mass of $R$. conicus; e number of the tephritid fly Paracantha culta; and $\mathbf{f}$ mass of $P$. culta, per flower head; treatment effects

significant in predicting individual weevil size (mass) within treatment $\left(F_{1,181}=24.109, P<0.001\right)$. These results, where weevils with priority access were largest, suggest that the native $P$. culta did have a evaluated by ANOVA/ANCOVA ( $F$ test, orthogonal contrasts among treatments). The treatments were: $F 0$ fly-only, $F 1$ flyfirst, $F W$ fly and weevil simultaneously, $W 1$ weevil-first, and WO weevil-only, with the treatments ordered (left to right) by increasing priority of access by the exotic invasive weevil, $R$. conicus, relative to the native fly, $P$. culta

negative effect $R$. conicus, decreasing individual weevil mass somewhat when the two species cooccurred, even though it had no effect on the number of successful weevils. 
Fig. 2 Responses of the tephritid fly, Paracantha culta, to increasing Rhinocyllus conicus biomass, correlated with increasing priority of the introduced weevil shown in Table 1 $(F 1, F W$ to $W 1$ and then to $W 0$ ) in the field priority access experiment: a least squares linear regression showing relationship of total fly biomass per head to R. conicus biomass per head; b individual female $(F)$ and male $(M)$ fly size $(\mathrm{mg})$ by treatment (treatment effect: $P<0.001$ for both sexes); and c $P$. culta biomass as a proportion of total insect biomass, by treatment $(P<0.001)$, where the dashed line represents the expected value under null hypothesis of equal, reciprocal competition between native fly $(P$. culta) and exotic weevil (R. conicus). The treatments were: $F 0$ fly-only, $F 1$ fly-first, $F W$ fly and weevil simultaneously, $W 1$ weevil-first, and $W O$ weevilonly, with the treatments ordered (left to right) by increasing influence of the exotic invasive weevil, $R$. conicus

\section{Fly numerical response}

As $R$. conicus priority access to flower head resources increased, the number of $P$. culta developing decreased significantly and systematically from fly-only (F0) and fly-first (F1) treatments, which did not differ significantly from each other, to the simultaneous treatment (FW) and, finally, to the weevil-first (W1) treatment (Fig. 1e; ANCOVA, square root-transformed head size as covariate, on square root-transformed counts, $P<0.001)$. The interaction reduced $P$. culta numbers as $R$. conicus priority increased. Among treatments with both species (Fig. 1e), fly success decreased $52.0 \%$ from the fly-first (F1) treatment to the simultaneous (FW) treatment and 58.9\% from the simultaneous treatment (FW) to the weevil-first (W1) treatment. In the dissections, we found no evidence to suggest that intra-guild predation by $R$. conicus occurred and caused mortality of $P$. culta larvae in the flower head. In sum, in treatments with both $P$. culta and $R$. conicus, the numbers of successful flies decreased severely as weevil priority access to floral resources increased, without any evidence of direct weevil-induced fly mortality.

\section{Fly total biomass response}

The response in fly biomass paralleled the pattern in fly numbers (Fig. 1f), with decreased fly biomass as $R$. conicus biomass increased in co-occurrence (Fig. 2a), and increased weevil biomass correlated with increased weevil priority (Table 1). Total biomass of $P$. culta flies per flower head differed significantly among the five priority treatments (ANCOVA, square-root transformed head size as
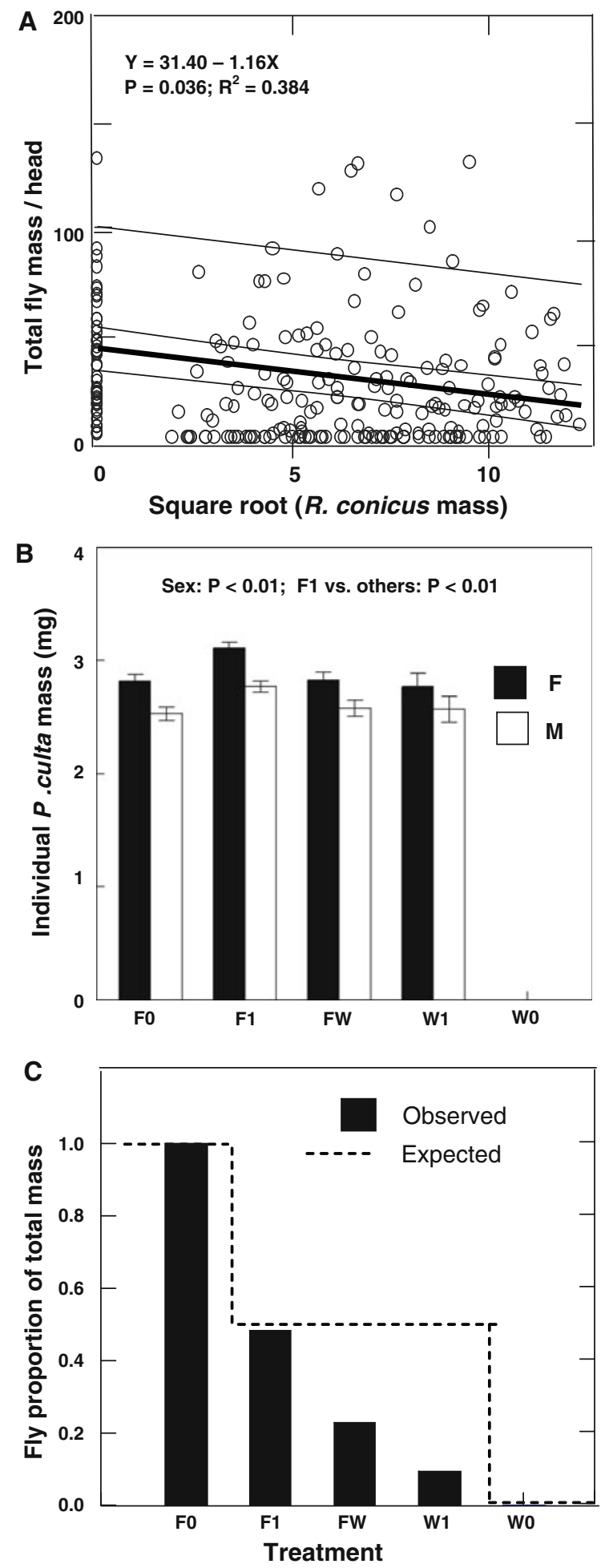

covariate, on square-root transformed proportion total insect biomass: $F_{4,226}=53.837, P<0.001$ ). Mean number of flies per head did not differ between fly 
only (F0) and fly first (F1), nor between weevil first (W1) and weevil only (W0); however, among treatments with both species, fly biomass declined significantly as $R$. conicus priority increased (Fig. 1f); the decreases amounted to $51.5 \%$ and $73.7 \%$ in total fly biomass from $\mathrm{F} 1$ to $\mathrm{FW}$ and from $\mathrm{FW}$ to $\mathrm{W} 1$ respectively, even though the treatments started with comparable numbers of insects and differed only in timing of access. Results in the earlier, smaller experiment were comparable (Online Resource 1).

Further, when the two species co-occurred, the relative contribution of $P$. culta flies to total insect biomass decreased significantly as $R$. conicus priority increased (ANOVA on arcsine-transformed proportions: $\left.F_{4,224}=442.672, P \ll 0.001, R^{2}=0.894\right)$. In fact, the fly contribution was much lower than expected in the concurrent (FW) and weevil first (W1) treatments, with the expected value based on the null hypothesis of equal, reciprocal competition between $P$. culta and $R$. conicus (observed $=$ bars, expected $=$ dashed line: Fig. $2 \mathrm{c}$ ). When the two species co-occurred, the negative effects of the interaction on the native fly increased as the introduced weevil priority increased; the proportionate contribution of flies to total insect biomass declined $51.7 \%$ from fly-first (W1) treatment to the simultaneous $(\mathrm{FW})$ treatment, and $58.4 \%$ from $\mathrm{FW}$ to the weevil-first (F1) treatment. Thus, in co-occurrence, stepwise increases in $R$. conicus priority led to significant absolute and relative decreases in $P$. culta fly biomass, as well as in the fly numbers.

\section{Individual fly size response}

Since insect fecundity is generally related to insect size, we examined change in individual insect size (mass) by sex across the priority treatments. Females were larger than males on average (Fig. 2b). Individual fly mass by sex varied among treatments (Fig. 2b; Kruskal-Wallis ANOVA: female flies, $H_{3}=21.194, P<0.001$; male flies, $H_{3}=11.861$, $P<0.01)$. Both female and male $P$. culta were significantly larger in the fly-first (F1) treatment (females: $3.01 \mathrm{mg}$, males: $2.73 \mathrm{mg}$ ) than in the other treatments with flies (females: 2.59, 2.70 and $2.94 \mathrm{mg}$; and males: $2.28,2.59$ and $2.61 \mathrm{mg}$, in the F0, FW and W1 treatments, respectively), consistent with the earlier experiment (Online Resource 1:
Results). The smaller individual sizes of $P$. culta in the fly-only treatment (F0) than in the fly-first treatment $(\mathrm{F} 1)$ could not be explained by any of the measurements we took (Table 1). However, critically, among the treatments where the two species cooccurred and varied only in timing of access (F1, FW, $\mathrm{W} 1$ ), both female and male individual fly sizes, and so potential fecundity and lifetime fitness, were lower when $R$. conicus had either equal (FW) or earlier access (W1) to flower head resources than in the flyfirst treatment (F1), where P. culta had the temporal advantage. Comparable results occurred in the preliminary experiment (On-Line Resource 1).

\section{Spatial displacement of $P$. culta by $R$. conicus}

Foraging niche of $P$. culta within the flower head, measured as fly position in relation to the highly nutritive receptacle resources (see "Methods"), was severely and progressively disrupted as $R$. conicus priority increased (Fig. 3). For example, among treatments with both species, the number and proportion of $P$. culta deeply buried into the receptacle resources was inversely related to the degree of $R$. conicus priority on a head (Fig. 3a, b). These results are consistent with the larger individual female fly size in co-occurrence when $P$. culta had priority access (F1) versus when the $R$. conicus had equal or higher priority access (FW, W1) to floral resources (Fig. 2b). Overall, in co-occurrence, $P$. culta was increasingly excluded from the nutritious receptacle resources with increasing $R$. conicus priority access to those resources.

\section{Feeding damage}

The proportion of seeds eaten or severely damaged per flower head increased significantly when $R$. conicus was present, from $60 \%$ in the fly-only (F0) treatment to $88-96 \%$ in the treatments with the weevil added (Table 1; Kruskal-Wallis ANOVA on arcsine-transformed proportion damaged, $P<$ 0.001). Also, the number of intact seeds remaining, representing unexploited resources, decreased significantly when $R$. conicus occurred (Table 1): from an average of 23.2 undamaged seeds per flower head in the fly-only (F0) treatment to only $0.3-2.3$ 

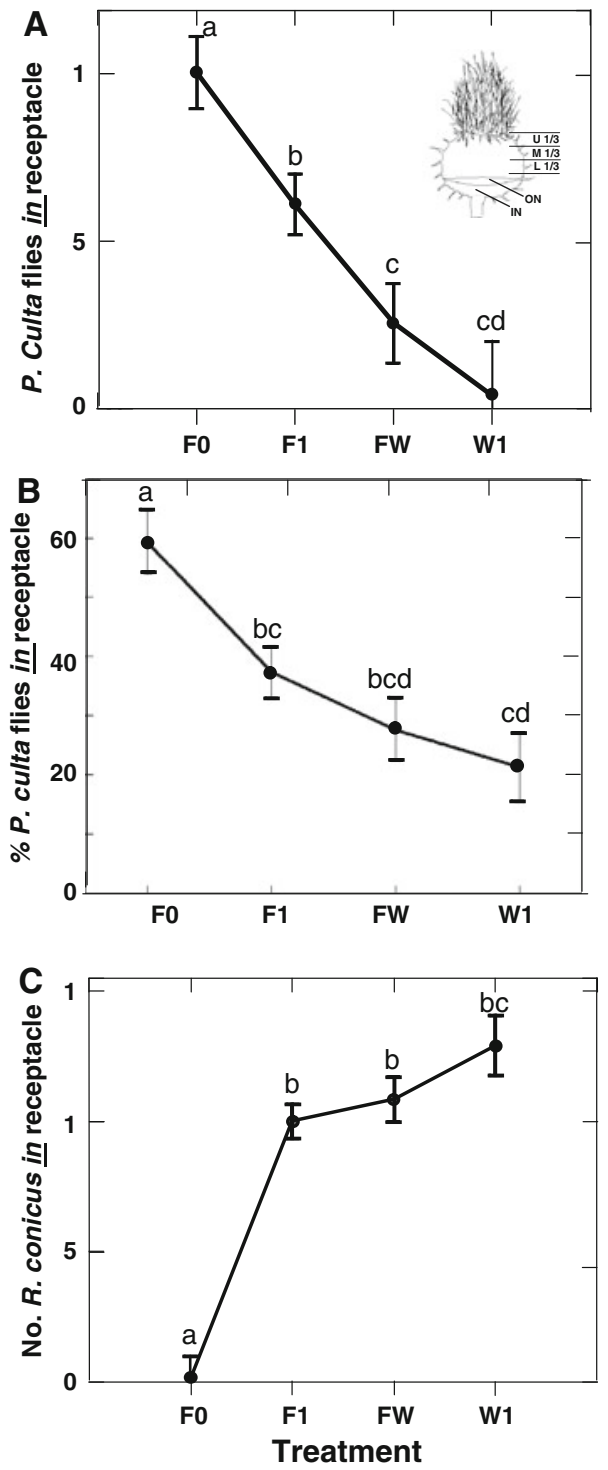

undamaged seeds in the treatments with $R$. conicus data recorded in the field $(P<0.001)$, results which parallel the reported field data (Louda and Potvin 1995; Louda et al. 1997, 2005b). Thus, the resource depletion caused by $R$. conicus feeding reduced the seed resources remaining dramatically (tenfold) in co-occupied heads. Overall, the co-occurrence of and priority access by the introduced weevil $R$. conicus with $P$. culta led to significant decreases in the total fly numbers, total fly biomass and individual fly sizes, and so potential fitness, on its native non-target host plant, C. canescens.
4Fig. 3 Variation in the number of $P$. culta in the optimal spatial position within a flower head, with fly and its mouth hooks burrowed deep into the nutritive receptacle base of the flower head (with phloem input), in relation to the priority of $R$. conicus within the flower heads by treatment in the field priority access experiment (least square means, SE), with position-scoring criteria illustrated in inset: a number of $P$. culta buried into the flower head receptacle surface $\left(F_{3,164}=11.589, P<0.001\right)$; b proportion of $P$. culta buried into the flower head receptacle surface $\left(F_{3,158}=9.617\right.$, $P<0.001)$; and c number of $R$. conicus feeding within the receptacle tissues $\left(F_{3,164}=45.23, P \ll 0.001\right)$. Analysis used ANCOVA (head size was a significant covariate; orthogonal contrasts among treatments). Treatments with flies present were: $F 0$ fly-only, $F 1$ fly-first, $F W$ fly and weevil simultaneously, and $W 1$ weevil-first, with the treatments ordered (left to right) by increasing priority and influence of the exotic invasive weevil, $R$. conicus. The results show that native fly access to the nutrient rich resources of the receptacle decreased as weevil priority and use of the receptacle resources increased

Projected fly population sizes

with versus without the weevil

The individual based model (IBM) shows that populations of $P$. culta flies are likely to be negatively affected, by both $R$. conicus co-occurrence and flower head resource limitation. The long-term stochastic carrying capacity $\left(K_{\mathrm{s}}\right)$ of the fly population declined as the level of $R$. conicus infestation increased (Fig. 4a). Further, $K_{\mathrm{s}}$ for the fly population declined as $R$. conicus priority strength increased (Fig. 4b). Finally, $K_{\mathrm{s}}$ also declined as flower head resource availability decreased; specifically, fly populations with $R$. conicus present had lower overall population numbers relative to fly-only populations at any given resource level (Fig. 4c). As a result, the additive effects of $R$. conicus and resource limitation should drive fly populations even lower than the presence of $R$. conicus alone (Fig. 4c). Overall, the demographic inference from the model is that $R$. conicus co-occurrence and priority access, in the context of resource constraint, has the potential of leading to decreased population sizes of the native tephritid fly $P$. culta on its co-evolved native host plant.

\section{Discussion}

Research on the non-target effects of invasive weed biocontrol agents is generally focused on inter-trophic 

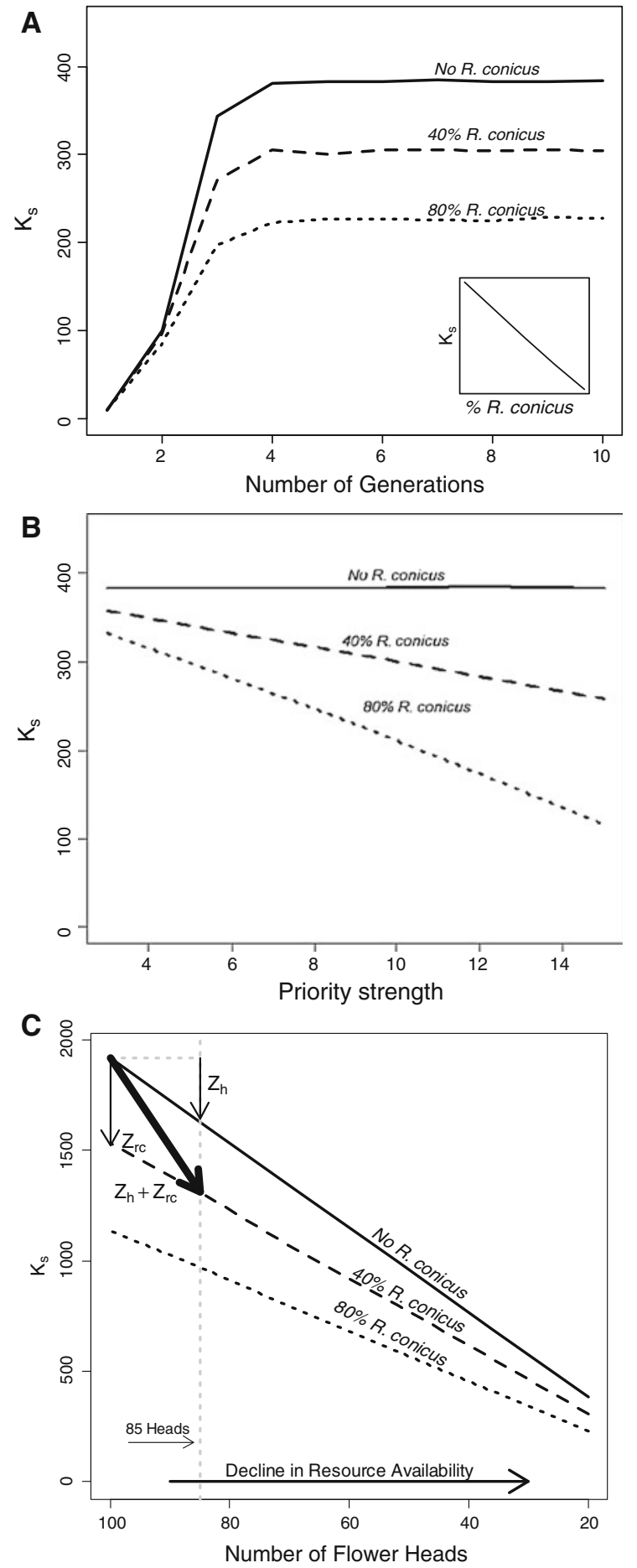

level effects of the introduced insect on the newly adopted native host plant. However, more complex pathways of interaction characterize communities (e.g., Pearson and Callaway 2003). The aim of this study was to experimentally evaluate one such
4Fig. 4 Fly population stochastic carrying capacity $\left(K_{\mathrm{s}}\right)$ predicted by the individual based model $(\beta=3, \eta=10)$. a Effect of increasing $R$. conicus infestation of 20 flower heads (Inset: illustrates how $K_{\mathrm{s}}$ changes with increased frequency of $R$. conicus infestation). b Effect of increasing the strength of the priority. Even a relatively low priority strength of $R$. conicus reduced the predicted carrying capacity of fly populations supported by 20 flower heads. c Effect of resource availability on $K_{\mathrm{s}}$. The arrow denoted by $Z_{\mathrm{h}}$ illustrates the effect of declining resources, e.g. from 100 to 85 flower heads (along dashed line) in the absence of $R$. conicus, and the arrow denoted by $Z_{\mathrm{rc}}$ illustrates the effect of $40 \% R$. conicus infestation alone. The bold arrow $\left(Z_{\mathrm{h}}+Z_{\mathrm{rc}}\right)$ shows the predicted effect of $R$. conicus infestation assuming the $R$. conicus infestation also reduced resource availability

interaction, the putative intra-trophic level competition between the invasive flower head weevil, $R$. conicus, and the native tephritid fly, P. culta, mediated through the floral resources of the weevil's newly adopted, non-target native host plant, Platte thistle, C. canescens. We quantified the competitive interaction and assessed whether priority resource access influenced the outcome and intensity of competition between the two insects. We also determined the effect of priority access by the weevil on $P$. culta pre-oviposition behavior and post-oviposition development, as potential mechanisms that could underlie the observed competitive effects. Finally, we developed an IBM to explore the demographic implications of the experimental data. The results provide strong evidence that biological control agents can exert significant non-target effects on native species through complex competitive mechanisms, potentially reducing numbers of the affected native species, and so producing unanticipated, non-target, "ripple" effects within communities.

Role of priority access in the intensity and outcome of interaction

Overall, $R$. conicus had strong competitive effects on the co-occurring native tephritid fly, P. culta. Both the total numbers and the biomass of the flies were significantly lower in the presence of $R$. conicus on the flower head resource. When the two species cooccurred within a flower head, mean individual fly size (mass) by sex, a parameter of fitness, was greater when the fly had priority than when $R$. conicus had simultaneous or prior access. Further, total fly mass decreased as total $R$. conicus mass increased in a 
flower head (Fig. 2). These experimental results are consistent with our initial experiment (On-Line Resource 1) and with the available evidence suggesting that invasive insect herbivores have the potential of exerting negative effects on native competitors (reviewed in Kenis et al. 2009). The results here also are consistent with the evidence showing that competition often occurs among overlapping biological control agents (Berube 1980; Smith and Mayer 2005; Hunt-Joshi and Blossey 2005; Crowe and Bouchier 2006). To our knowledge, however, this study provides the first experimental evidence demonstrating strong negative competitive effects of an introduced weed biological control agent on a resident native insect herbivore associated with a newly adopted, non-target native host plant.

Priority access to flower head resources by $R$. conicus strongly increased the intensity of competition and the weevil's impact on the native tephritid fly, $P$. culta. The native fly escaped the competitive effects of the introduced weevil only when the flies had sole or priority access to a flower head. Fly numbers, total biomass and individual size (mass) were strongly competitively suppressed whenever oviposition by $P$. culta was either synchronized with, or followed, oviposition by $R$. conicus.

Further, the competitive effects were highly asymmetric. Priority access to the floral resources benefited the native fly more than the introduced weevil when the two species co-occurred. Both the numbers and the biomass of $P$. culta in flower heads with both species dropped dramatically as $R$. conicus priority increased (Fig. 1). Alternately, the only evidence that $R$. conicus was affected, even somewhat, by the presence or timing of $P$. culta attack was that individual weevil mass was highest in the weevil-only (W0) treatment, without any flies. Neither weevil numbers nor total weevil biomass per flower head were altered by weevil priority access to the floral resources. These results add to the evidence compiled in a meta-analysis (Kaplan and Denno 2007) showing that competition between insect herbivores is often highly asymmetric.

Other studies of floral herbivore interactions also have found strong asymmetries in floral competition between weevils and tephritid flies in co-occurrence. For example, two studies evaluated the interaction of two floral-feeding biocontrol insects on knapweed (Centaurea spp) flower heads. Crowe and Bouchier
(2006) found that both the rate of attack by, and the total numbers of, the weevil Larinus minutus Gyllenhal were decreased significantly in the presence of the gallinducing tephritid fly, Urophora affinis Frauenfeld. However, Smith and Mayer (2005) found no evidence of a competitive effect of $U$. affinis on L. minutus; instead, the presence of the weevil led to significant decreases in the fly (U. affinis). Both studies document an interaction between the floral insects. The discrepancy between the two studies, however, likely can be explained by a difference in the timing of attack (Crowe and Bouchier 2006). In the field, U. affinis uses flower heads before L. minutus does and so has priority, potentially allowing the galling flies to successfully sequester floral resources before the weevil oviposits. In Smith and Mayer's (2005) study, however, both insects were released into cages simultaneously, establishing synchrony of attack and likely increasing the competitive effect of the weevil on the fly (Crowe and Bouchier 2006). These studies of interactions between biological control agents suggest that the timing, or priority, of insect attack actually altered the competitive hierarchy between the floral feeding insects. In contrast, in our study the invasive weevil was generally the superior competitor. We found that the numbers of $R$. conicus were not reduced by the presence of the fly, regardless of the relative timing of attack (Fig. 1c). Yet, the numbers and performance of the native tephritid $P$. culta (Figs. 1,2,3) were strongly and negatively suppressed by presence of the weevil, $R$. conicus, when weevil attack of flower heads preceded or coincided with that of flies.

Multiple mechanisms led to competitive outcomes

Priority access to a shared resource can confer an advantage through a variety of direct (interference) and indirect (exploitation) competitive mechanisms. When both species co-occurred, we found that flies were displaced from the receptacle, clear evidence for interference competition from the weevils that came from below; and, we found numerical and size differences related to the priority access treatment, highly suggestive evidence for exploitative competition as a factor in explaining the strong effects of $R$. conicus on $P$. culta.

The laboratory data on pre-oviposition behavior by the fly showed that prior oviposition by $R$. conicus 
interfered at least partially with flower head use and oviposition by $P$. culta. The native flies spent less time actively exploring and ovipositing on heads to which $R$. conicus had had prior access than on heads with no evidence of weevil oviposition, although priority weevil access did not preclude fly use completely. Partial fly avoidance of flower heads with $R$. conicus eggs supports long-term field observations that show that as $R$. conicus numbers increased with invasion, $P$. culta numbers decreased (Louda and Arnett 2000; Louda et al. 2005b). The inference from the laboratory experiment and the related field data is that the demographic impacts emerging from the individual-based model include some shift in fly use to less preferred, later developing, smaller, and so inferior, flower head resources, which will depend upon the availability of other suitable floral resources. Quantitative evaluation of this inference remains to be done.

Results from the field experiment examining the effects of post-ovipositional interactions suggested that the competitive effects of $R$. conicus on $P$. culta in co-occurrence were mediated by both exploitative competition for limited resources in smaller flower heads or in heads with high insect densities, and by interference competition, via spatial displacement of flies to lower quality resources, in larger flower heads or at lower total insect densities. At least three lines of evidence suggest that exploitation competition contributed to the strong competitive effect of $R$. conicus on $P$. culta. First, flower head size, a measure of resource availability, was consistently a highly significant covariate in explaining within treatment variation of both numbers and biomass of insects, as well as numbers and performance of $P$. culta developing in a flower head; larger heads have more insects and greater insect success. These results suggest that decreased resources intensify the consequences of post-oviposition competition. This is consistent with field observations, where smaller heads tend to have only one of the two species developing, despite evidence of oviposition by both (S. Louda, unpublished data). Second, in co-occurrence both the number and biomass of successful $P$. culta flies decreased as the number of insects, especially $R$. conicus, increased. Finally, third, the remaining, unconsumed resources within a flower head, measured as the number of matured intact seeds remaining, decreased dramatically as $R$. conicus presence and priority increased and $P$. culta abundance and biomass decreased. Together, these three lines of evidence suggest that the floral feeding insects are often resource-limited, and that the addition of $R$. conicus significantly decreases resource availability to $P$. culta.

Further, the evidence shows interference occurred in the larger heads, ones in which both insects developed. When the two species co-occurred, the number of $P$. culta in contact with the highly nutritive tissues of the receptacle decreased as the priority and number of $R$. conicus increased. Such competitively mediated spatial niche shifts, a form of interference competition in which the inferior or later-arriving competitor is physically displaced to poorer feeding sites, are quite common within insect communities (Denno et al. 1995). Here, the degree of fly displacement within flower heads was directly proportional to the degree of priority access by $R$. conicus, suggesting that simultaneously- or earlier-arriving weevils interfered directly with feeding by the native fly. Fly mass, recorded for the flies surviving in co-occupied heads, decreased as weevil mass increased (Fig. 1; On-Line Resource 1); and, weevil mass increased as weevil priority increased among the treatments $(\mathrm{F} 1 \leq \mathrm{FW} \leq$ W1: Fig. 1). Thus, fly displacement to increasingly distant, likely inferior feeding positions away from the nutrient-rich receptacle in co-occurrence provides an explanation for the significant declines in successful $P$. culta numbers, total mass, and individual fly size by sex observed as $R$. conicus priority, presence and mass increased.

Cumulatively, the results suggest that a combination of mechanisms underlie the overall competitive effects of the weevil $R$. conicus on the native tephritid fly $P$. culta. These mechanisms include: (1) preovipositional interference, mediated by at least partial fly oviposition avoidance of flower heads previously colonized by the weevil; (2) post-oviposition resource use and depletion, mediated by flower head size and, so, resource availability; and, (3) spatial displacement from preferred feeding sites, resulting in interference with fly feeding, in larger flower heads.

Demographic implications of the experimental data

The individual based model (IBM) showed that the competitive interactions documented here can cause 
decreases in the population size of $P$. culta flies. Both resource limitation and $R$. conicus priority and level of infestation affected the stochastic carrying capacity $\left(K_{\mathrm{s}}\right)$ for the fly population. Sustainable numbers of flies dropped as the $R$. conicus infestation was increased or as weevil priority was increased. Thus, the additive effects of resource limitation, now associated with declines in $C$. canescens populations (Rose et al. 2005), and $R$. conicus occurrence are likely to decrease populations of $P$. culta. Specific model predictions of demographic impacts and underlying mechanisms are open to test with further experimental and observational data. In sum, the individual based model results, which are consistent with extensive field data suggesting an inverse relationship between the numbers of the native fly and the invasive weevil (Louda and Arnett 2000; Louda et al. 2005b, Russell and Louda 2004, 2005, and S. Louda, unpublished data), implies that both occurrence and priority access of the weevil $R$. conicus could have a strong negative effect on $P$. culta population density.

\section{Inferences for invasion outcomes}

The experimental results here demonstrate strong competitive effects of an invasive insect on the native fly, Paracantha culta, both before co-occurrence (pre-oviposition) and in co-occurrence (post-oviposition) within individual thistle flower head resource packets. Further, the IBM model results show that such interactions can have significant, negative demographic consequences for the native fly population. Although the direct trophic effects of biological control agents on non-targeted native hosts are increasingly documented (Simberloff and Stiling 1996; Louda et al. 1997, 2005b; Louda 2000; Louda and Arnett 2000), our understanding of the complex direct and indirect pathways and mechanisms by which such non-target interactions ripple through communities remains in its infancy (Pearson and Callaway 2003). The experimental results presented here unequivocally demonstrate that not only native plants, but also their associated native herbivores, can be significantly affected by the host range expansion of a weed biological control insect. Further, the IBM model demonstrates the potential for significant, negative effects on the native fly populations. More generally, the research provides experimental and modeling support for the idea that competition can be an important mechanism underlying invasive species effects on native species within the same trophic guild.

Acknowledgments We thank Kayla Christensen for energetic help in the field, Chad Andersen and Nate Brandt for conscientious help in the lab, and Steve Archer for discussions on data handling and analyses of the initial experiment. We appreciate the logistical support provided by UNL Cedar Point Biological Station staff and the financial support provided by NSF grant DEB 96-15299 to S. M. L., a D. H. Smith Conservation Research Fellowship to T. A. R., and a Howard Hughes Medical Institute Scholarship for the Summer Independent Research Experience to A. A. R. K. We appreciate the stimulus for improvement provided by the comments of an anonymous reviewer, and the insightful suggestions of the Editor-in-Chief, Dan Simberloff. USDA is an equal opportunity provider and employer.

\section{References}

Agrawal AA, Ackerly DD, Adler F, Arnold AE, Caceres C, Doak DF, Post E, Hudson PJ, Maron J, Mooney KA, Power M, Schemske D, Stachowicz J, Strauss S, Turner MG, Werner E (2007) Filling key gaps in population and community ecology. Front Ecol Environ 5:145-152

Berube DE (1980) Interspecific competition between Urophora affinis and $U$. quadrifasciata (Diptera: Tephritidae) for ovipositional sites on diffuse knapweed (Centaurea diffusa: Compositae). J Appl Entomol 90:299-306

Crowe M, Bouchier R (2006) Interspecific interactions between the gall-fly Urophora affinis Frfld. (Diptera: Tephritidae) and the weevil Larinus minutus Gyll. (Coleoptera: Curculionidae), two biological control agents released against spotted knapweed, Centaurea stobe L. ssp. micranthos. Biocontrol Sci Tech 16:417-430

Denno RF, McClure MS, Ott JR (1995) Interspecific interactions in phytophagous insects: competition reexamined and resurrected. Ann Rev Entomol 40:297-331

Gandhi KJK, Herms DA (2010) Direct and indirect effects of alien insect herbivores on ecological processes and interactions in forests of eastern North America. Biol Invasions 12:389-405

Gassmann A, Louda SM (2001) Rhinocyllus conicus: initial evaluation and subsequent ecological impacts in North America. In: Wajnberg E, Scott JK, Quimby PC (eds) Evaluating indirect ecological effects of biological control. CABI International, Wallingford, pp 147-183

Goeden RD, Andres LA, Freeman TE, Harris P, Pienkowski RL, Walker CR (1974) Present status of projects on the biological control of weeds with insects and plant pathogens in the United States and Canada. Weed Sci 22:490-495

Headrick D, Goeden RD (1990) Life history of Paracantha gentilis (Diptera: Tephritidae). Ann Entomol Soc Am 83:776-785 
Howarth FG (1990) Hawaiian terrestrial arthropods: an overview. Bishop Mus Occas Pap 30:4-26

Hunt-Joshi T, Blossey B (2005) Interactions of root and leaf herbivores on purple loosestrife (Lythrum salicaria). Oecologia 142:554-563

Kaplan I, Denno R (2007) Interspecific interactions in phytophagous insects revisited: a quantitative assessment of competition theory. Ecol Lett 10:977-994

Kaul RB (1989) Plants. In: Bleed A, Flowerday C (eds) An atlas of the Sand Hills. University of Nebraska-Lincoln, Lincoln, pp 127-142

Kaul RB, Sutherland D, Rolfsmeier S (2007) The flora of Nebraska. Conservation and Survey Division, School of Natural Resources, Institute of Agriculture and Natural Resources, University of Nebraska, Lincoln

Keeler KH, Harrison AT, Vescio L (1980) The flora and Sand Hills prairie communities of Arapaho Prairie, Arthur County, Nebraska. Prairie Nat 12:65-78

Kenis M, Auger-Rozenberg M-A, Roques A, Timms L, Pere C, Cock JW, Settele J, Augustin S, Lopez-Vaamonde C (2009) Ecological effects of invasive alien insects. Biol Invasions 11:21-45

Lalonde RB, Roitberg BD (1992) Host selection behavior of a thistle-feeding fly: choices and consequences. Oecologia 90:534-539

Lamp WO, McCarty MK (1981) Biology and ecology of Platte thistle (Cirsium canescens). Weed Sci 29:686-692

Lamp WO, McCarty MK (1982a) Biology of predispersal seed predators of the Platte thistle Cirsium canescens. J Kans Entomol Soc 55:305-316

Lamp WO, McCarty MK (1982b) Predispersal seed predation of a native thistle, Cirsium canescens. Environ Entomol 11:847-851

Levine JM, Vila M, D’Antonio CM, Dukes JS, Grigulis K, Lavorel S (2003) Mechanisms underlying the impact of exotic plant invasions. Proc R Soc Lond Ser B Biol Sci 270:775-781

Louda SM (1998a) Population growth of Rhinocyllus conicus (Coleoptera: Curculionidae) on two species of native thistles in prairie. Environ Entomol 27:834-841

Louda SM (1998b) Ecology of interactions in biological control practice and policy. Bull Br Ecol Soc 294:8-11

Louda SM (2000) Negative ecological effects of the musk thistle biocontrol agent, Rhinocyllus conicus Fröl. In: Follet PA, Duan JJ (eds) Nontarget effects of biological control. Kluwer, Boston, pp 215-243

Louda SM, Arnett AE (2000) Predicting non-target ecological effects of biological control agents: evidence from Rhinocyllus conicus. In: Spencer NR (ed) Proceedings of the 10th international symposium on the biological control of weeds. Montana State University, Bozeman, pp 551-567

Louda SM, Potvin MA (1995) Effect of inflorescence-feeding insects in the demography and lifetime fitness of a native plant. Ecology 76:229-245

Louda SM, Kendall D, Connor J, Simberloff D (1997) Ecological effects of an insect introduced for the biological control of weeds. Science 277:1088-1090

Louda SM, Arnett AE, Rand TA, Russell FL (2003a) Invasiveness of some biological control insects and adequacy of their ecological risk assessment and regulation. Conserv Biol 17:73-82

Louda SM, Pemberton RW, Johnson MT, Follett PA (2003b) Nontarget effects-the Achilles' Heel of biological control? Retrospective analyses to reduce risk associated with biocontrol introductions. Ann Rev Entomol 48:365-396

Louda SM, Rand TA, Arnett AE, McClay AS, Shea K, McEachern AK (2005a) Evaluation of ecological risk to populations of a threatened plant from an invasive biocontrol insect. Ecol Appl 15:234-249

Louda SM, Rand TA, Russell FL, Arnett AE (2005b) Assessment of ecological risks in biocontrol: input from retrospective ecological analyses. Biol Control 35:253-264

Maron JL, Vila M (2001) When do herbivores affect plant invasion? Evidence for the natural enemies and biotic resistance hypotheses. Oikos 95:361-373

Nufio CR, Papaj DR (2001) Host marking behavior in phytophagous insects and parasitoids. Entomol Exp Appl 99:273-293

Parker IM, Simberloff D, Lonsdale WM, Goodell K, Wonham M, Kareiva PM, Williamson H, Holle BV, Moyle PB, Byers JE, Goldwasser L (1999) Impact: toward a framework for understanding the ecological effects of invaders. Biol Invasions 1:3-19

Pearson DE, Callaway RM (2003) Indirect effects of hostspecific biological control agents. Trends Ecol Evol 18:456-461

Rand TA, Louda SM (2006) Invasive insect abundance varies across the biogeographic distribution of a native host plant. Ecol Appl 16:877-890

Rees NE (1982) Collecting, handling and releasing Rhinocyllus conicus, a biological control agent of musk thistle. Agric Res Serv USDA 579:1-7

Rose KA, Louda SM, Rees M (2005) Demographic and evolutionary impacts of native and invasive insect herbivores: a case study with Platte thistle, Cirsium canescens. Ecology 86:453-465

Russell FL, Louda SM (2004) Phenological synchrony affects interaction strength of an exotic weevil with Platte thistle, a native host plant. Oecologia 139:525-534

Russell FL, Louda SM (2005) Indirect effects mediate floral herbivory on a native thistle by an invasive exotic insect. Oecologia 146:373-384

Simberloff D, Stiling P (1996) How risky is biological control? Ecology 77:1965-1974

Smith L, Mayer M (2005) Field cage assessment of interference among insects attacking seed heads of spotted and diffuse knapweed. Biocont Sci Technol 15:427-442

White E, Wilson J, Clarke AR (2006) Biotic indirect effects: a neglected concept in invasion biology. Divers Distrib 12:443-455

Wolfe LM (2002) Why alien invaders succeed: support for the escape-from-enemy hypothesis. Am Nat 160:705-711

Zwölfer H, Harris P (1984) Biology and host specificity of Rhinocyllus conicus (Froel.) (Col., Curculionidae), a successful agent for biocontrol of the thistle, Carduus nutans L. Zeit Ang Entomol 97:36-62 


\section{RESOURCE 1: SMALL-SCALE PRELIMINARY FIELD TEST}

\section{METHODS}

As an initial test of the interaction between the invasive biocontrol weevil, Rhinocyllus conicus, and the native tephritid flies (Paracantha culta, Orellia occidentale), we measured all flower heads $\geq 12$ mm diameter $(n=1-3$ per plant, median $=1)$ on 60 plants on $25-29$ May 1999. Then, we removed any smaller flower head buds and covered each experimental flower head with a large (1 1 volume) clear plastic cage with mesh windows; the cage was supported by an adjacent pole. Flower heads within and between plants were assigned to one of four treatments by blocking on head size and head position within a plant; and, treatments were randomly assigned within blocks ( $\mathrm{n}=15$ flower heads per treatment). The four treatments were, in the order of increasing $R$. conicus influence: flies-only (F0), flies-first followed by weevils (F1), weevils-first followed by flies (W1), and weevils-only (W0). We used insects caught in the field and held in the lab $(<7$ d) until the treatment were established $4-6$ June 1999 . We added five flies of one tephritid species (50\% fly-added cages received P. culta; $50 \%$ received $O$. occidentale $)$ for the first two treatments $(\mathrm{F} 0, \mathrm{~F} 1)$; the flies remained in the cages for $4 \mathrm{~d}$. At the same time, we added four weevils ( 2 mating pairs) to cages of the other two treatments (W1, W0); the weevils remained in the cage until a target number of eggs, determined from field observations and based on flower head size, had been laid $(\leq 6 \mathrm{~d})$. In the two priority treatments (F1, W1), we gave the insect with priority $6 \mathrm{~d}$ to establish before adding the second insect species, which then was allowed to remain for $4-6 \mathrm{~d}$, as above. Flower heads were kept covered by the cage for the rest of the season, except for $\sim 48 \mathrm{~h}$ when the flowers were in anthesis to allow natural pollination. Upon maturation, we collected the flower heads, dissected them, and counted and weighed all insects and recorded feeding damage. 
Dissection showed that the initial treatment assignment was compromised for eight flower heads. Two heads initially assigned to weevil only (W0) also produced P. culta; fly oviposition must have occurred prior to our caging and addition of weevils, suggesting these heads belonged in the fly first (F1) treatment. One head in the weevil first (W1) treatment produced no weevils but only flies, suggesting this head belonged in the flies only (F0) treatment. Finally, five heads to which $O$. occidentale had been added produced only $P$. culta, indicating that $P$. culta had oviposited earlier than our subsequent treatment and suggesting these heads belonged in the fly first (F1) treatment. We compared responses for these eight naturallyimposed treatments with the experimentally-imposed treatments, with using Kruskal-Wallis ANOVA on ranks. Since we found no statistical difference in the number of flies in these heads by treatment $(P=0.367)$, the eight heads were included in the treatment suggested by the dissection data. Given these re-assignments along with the death of several plants and their flower heads, final sample sizes by treatment were: 8 fly only (F0), 18 fly first (F1), 5 weevil first (W1), and 4 weevil only (W0) replicates.

We analyzed treatment effect on: numbers of insects, insect weight (mass), difference in proportion of the receptacle damaged, and numbers of intact seed resources remaining, using one-way analysis of variance (ANOVA) followed by Student's t test with the Bonferroni correction. However, when the underlying assumptions for parametric ANOVA were not met, we used nonparametric Kruskal-Wallis ANOVA on ranks.

\section{RESULTS}

The four treatments were effective in altering resource access between $R$. conicus and the native flies. No difference occurred between fly species (Kruskal Wallis ANOVA, P > 0.20), so 
we combined the two flies in subsequent analyses. As planned, flower heads with $R$. conicus added (F1, W1, W0) had significantly more weevil egg cases $(8.0-8.5)$ than did flower heads in the fly-only (F0) treatment (0.0) (Table 1; Kruskal Wallis ANOVA, P < 0.001).

\section{Numerical Responses}

The total number of insects developing per flower head was similar among treatments (Table $1, \mathrm{P}=0.322)$, although there was a trend toward higher total numbers in the fly first $(\mathrm{F} 1)$ treatment.

The total number of $R$. conicus developing per flower head did not differ significantly among the treatments with weevils added (Figure 1A, P > 0.20 in all contrasts); however, as planned, the number of weevils developing was significantly higher in weevil-added treatments than in the fly-only (F0) treatment (Figure 1A; ANCOVA, flower head size as covariate: $\mathrm{F}_{3,31}=$ 34.487, $\left.\mathrm{P}<0.001, \mathrm{R}^{2}=0.770\right)$. Timing of $R$. conicus development was similar among the three weevil-added treatments, since the proportion of immature weevils remaining as the plants senesced did not differ among weevil-added treatments (ANOVA: $F_{2,22}=0.410, P=0.669$ ).

The total numbers of flies developing in a flower head decreased progressively and significantly as $R$. conicus priority access increased (Figure $1 \mathrm{C}$; ANOVA: $\mathrm{F}_{3,32}=3.485, \mathrm{P}=$ 0.027). Additionally, the relative contribution of native flies to the total number of insects in a flower head decreased as $R$. conicus priority increased: $41 \%$ in fly first (F1) vs. $15 \%$ in weevil first (W1) treatments. The number of flies developing in the treatment without weevils (F0) was significantly greater than in the treatment where weevils had priority (W1) (Tukey's HSD P = 0.034). The overall decrease represented a decrease in $P$. culta, the predominant native fly (from 9.4 to 0.0 per head), while numbers of $O$. occidentale, the later-occurring fly, actually increased: 
from 0.2 in fly-only (F0), to 2.0 in fly-first (F1) and weevil-first (W1) treatments (Table 1), suggesting both that $P$. culta is more negatively affected by interaction with $R$. conicus than $O$. occidentale was and also that $P$. culta out-competed $O$. occidental, explaining the increase in $O$. occidentale with the decrease in P. culta. Differences in the number of flies developing among treatments could not be explained by variation in flower head size (floral resource availability), since average flower head size (diameter) was similar across all treatments (Table 1). Overall, the total number of native flies declined in flower heads shared with $R$. conicus, and the decline in $P$. culta in particular was greater when the weevil had earlier access to the flower head resources.

\section{Biomass Responses}

Since insects vary in size, we also examined biomass response. The patterns in biomass paralleled the patterns in numbers (Figure 1). The total biomass of insects developing per flower head did not differ among treatments (Figure 1E; ANOVA, $\mathrm{F}_{3,32}=0.836, \mathrm{P}=0.568$ ). Thus, shifting priority of access from native fly to introduced invasive weevil did not substantially alter the total floral insect biomass developing in each flower head.

Weevil biomass was significantly higher in all three weevil-added treatments (F1, W1, W0) than in the fly-only (F0) treatment, showing the treatments worked as expected (Figure 1B; Kruskal Wallis ANOVA on ranks: $\mathrm{Q}=3.554, \mathrm{P}<0.05)$. Weevil biomass did not vary significantly among the three treatments with weevils added (Figure 1B; Kruskal Wallis ANOVA on ranks, $\mathrm{Q}=1.260, \mathrm{P}>0.05)$, suggesting flies had little or no effect on weevil performance as measured by biomass. 
Fly biomass, however, decreased significantly as $R$. conicus priority increased (Figure 1D; ANOVA: $\left.F_{3,32}=4.881, \mathrm{P}=0.007\right)$. Fly biomass was higher in the fly-only $(\mathrm{F} 0)$ treatment than in each of the other three treatments (pairwise t-tests, Holm-Sidak correction for multiple comparisons: all $\mathrm{t}>2.87$, all $\mathrm{P}<0.05$ ). Total fly biomass also declined as total $R$. conicus biomass increased (Figure $2 \mathrm{~A}$; regression $\mathrm{P}<0.01$ ). The relative contribution of flies to total insect biomass per head dropped $88.9 \%$ from the fly-only (F0) treatment to the weevil-first (W1) treatment (Table 1 ). So, $R$. conicus priority decreased both the development of $P$. culta biomass, as well as decreasing fly numbers (above).

The individual size of $P$. culta adults that developed, especially females, appeared negatively affected by increasing interaction with $R$. conicus as weevil priority increased (Figure 2B, $\mathrm{P}<0.001)$. Individual female $P$. culta tended to be bigger in the fly-only (F0) treatment (14.8 mg, SE 2.73) than in the fly-first (F1) treatment (10.6 mg, SE 0.82) (Mann-Whitney U = 27.0, $\mathrm{P}=0.062$ ). Individual male $P$. culta size did not differ statistically among treatments, although the trend also was for males to be bigger in the fly-only (F0) treatment (10.8 mg, SE 0.93) than in the fly-first (F1) treatment (8.6 mg, SE 0.90) (Mann-Whitney U = 22.0, P = 0.131). Reduced size of emerging flies, especially females, suggests a reduction in fitness, since egg production is generally related to insect body size.

\section{Resource Use}

Evidence of insect feeding damage to floral resources increased as the number of $R$. conicus increased, including fewer and fewer intact seed resources remaining (Table 1). Treatment differences were driven by much lower damage in the fly-only (F0) treatment than in the three treatments with weevils (ANOVA: $\mathrm{F}_{1,30}=6.370, \mathrm{P}=0.02$ ). The number of intact seeds 
remaining as unconsumed resources was significantly lower when weevils were present than when flies alone occurred (ANCOVA, head size as the covariate: Treatment $\mathrm{F}_{2,11}=4.356, \mathrm{P}=$ 0.011) . Overall, $R$. conicus dramatically reduced floral guild resources whenever it was present, helping explain the declines observed in the numbers, biomass and individual fly mass with increasing introduced weevil priority to flower head resources. 
Table 1. Parameters (X, SE) potentially affecting treatment response in the preliminary priority experiment, with the treatments ordered (left to right) by increasing influence of the exotic invasive weevil, Rhinocyllus conicus; differences among treatments were evaluated using ANOVA (F test), or Kruskal-Wallis ANOVA on ranks (H test) on non-normal variables.

\begin{tabular}{|c|c|c|c|c|c|c|c|c|c|c|}
\hline \multirow{2}{*}{ Per flower head: } & \multicolumn{2}{|c|}{$\begin{array}{l}\text { Fly-only } \\
\text { (F0) }\end{array}$} & \multicolumn{2}{|c|}{$\begin{array}{l}\text { Fly-first } \\
\text { (F1) }\end{array}$} & \multicolumn{2}{|c|}{$\begin{array}{l}\text { Weevil-first } \\
\text { (W1) }\end{array}$} & \multicolumn{2}{|c|}{$\begin{array}{l}\text { Weevil only } \\
\text { (W0) }\end{array}$} & \multirow[b]{2}{*}{ Test } & \multirow[b]{2}{*}{$P$} \\
\hline & $X$ & SE & $\mathrm{X}$ & SE & $\mathrm{X}$ & $\mathrm{SE}$ & $X$ & SE & & \\
\hline \multicolumn{11}{|l|}{ Number of insects: } \\
\hline$R$. conicus egg cases & $0 . \overline{0}$ & -- & 8.3 & 0.72 & 8.5 & 1.56 & 8.0 & 2.42 & $\mathrm{H}=$ & $<0.001$ \\
\hline Total number flies + weevils & 9.7 & 1.93 & 12.9 & 1.24 & 8.8 & 1.66 & 8.0 & 1.73 & $\mathrm{~F}=$ & 0.322 \\
\hline Number $P$. culta & 9.4 & 1.99 & 5.4 & 1.26 & 0.0 & 0.00 & 0.0 & -- & $\mathrm{F}=$ & $<0.001$ \\
\hline Number $O$. occidentale & 0.2 & 0.22 & 0.7 & 0.34 & 2.0 & 1.68 & 0.0 & -- & $\mathrm{F}=$ & 0.322 \\
\hline \multicolumn{11}{|l|}{ Final status: } \\
\hline Proportion fly biomass & 1.0 & 0.00 & 0.34 & 0.07 & 0.111 & 0.09 & 0.0 & -- & $\mathrm{H}=$ & $<0.001$ \\
\hline Final head width, mm & 26.2 & 1.24 & 25.4 & 0.92 & 20.6 & 3.06 & 25.5 & 2.77 & $\mathrm{~F}=$ & 0.264 \\
\hline Proportion receptacle damaged & 0.42 & 0.118 & 0.98 & 0.11 & 0.89 & 0.02 & 0.99 & 0.01 & $\mathrm{~F}=$ & 0.011 \\
\hline Seeds (resources) remaining & 48.1 & 14.82 & 21.3 & 8.02 & 0.0 & 0.00 & 3.8 & 3.80 & $\mathrm{H}=$ & 0.20 \\
\hline
\end{tabular}


Figure 1. Number and biomass of insects per flower head (least-square mean, SE): A, number Rhinocyllus conicus; B, biomass of $R$. conicus; $\mathrm{C}$, number native tephritid flies (Paracantha culta, Orellia occidentale); D, biomass of tephritid flies; E, total insect biomass; and, F, proportion of the flower head receptacle surface damaged by insect feeding. The treatments were: F0 = fly-only; F1 = fly-first; W1 = weevil-first; and W0 = weevil-only, ordered (left to right) by increasing priority of the invasive weevil, $R$. conicus.
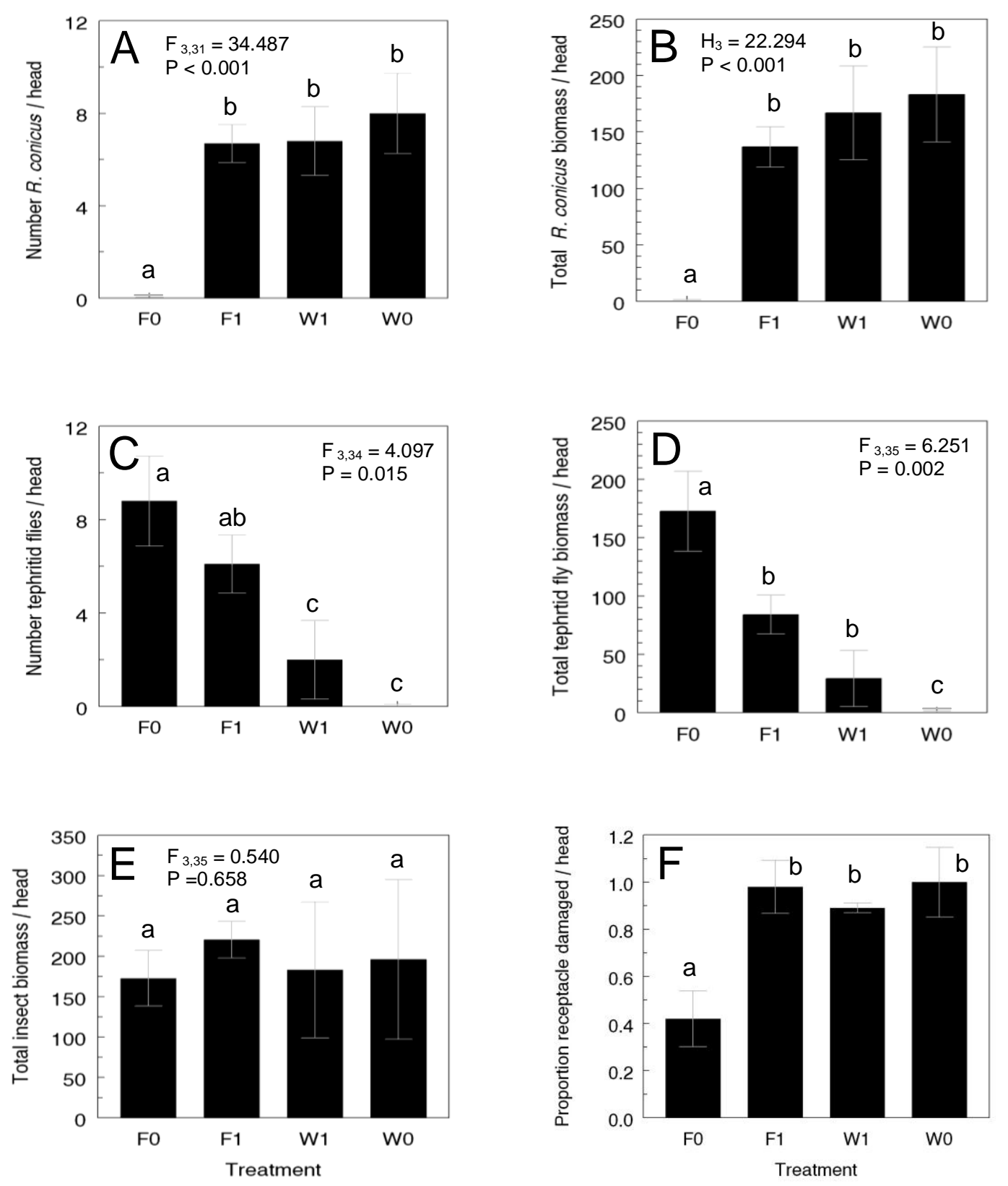
Louda et al. - Priority Resource Access of an Invasive Weevil 9

Figure 2. Least squares regressions showing the relationships for: A, total fly biomass to total $R$. conicus biomass per head; and, $\mathrm{B}$, individual fly biomass to total $R$. conicus biomass per head (square root-transformed) in the preliminary insect priority access experiment on Platte thistle (Cirsium canescens). The priority access treatments were: F0 = fly-only; F1 = fly-first; $\mathrm{W} 1$ = weevil-first; and W0 = weevil-only.
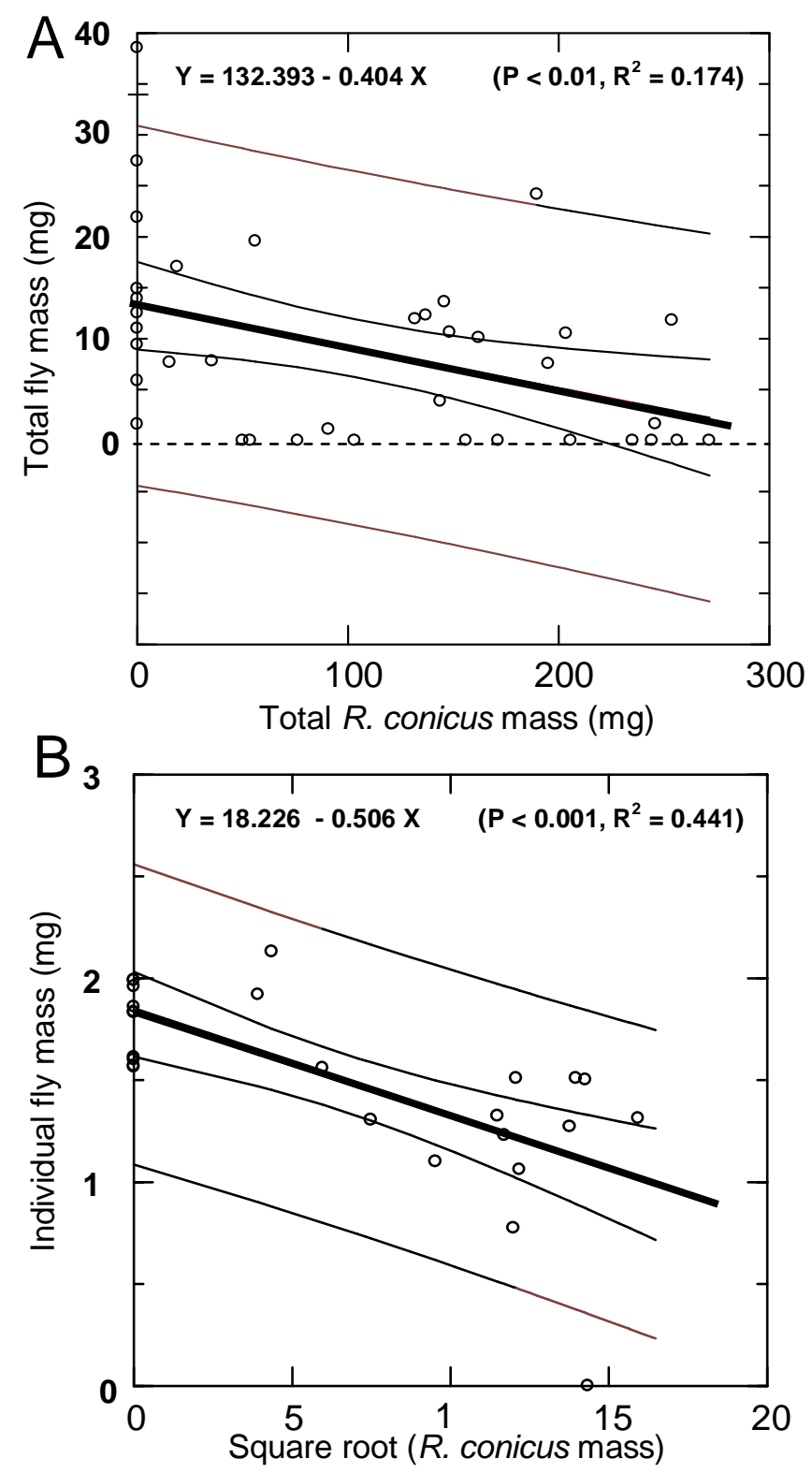


\section{RESOURCE 2: Individual-Based Model (IBM) Parameter Estimation Details}

I. Effect of changes in the shape parameter $(\beta)$ on the oviposition probability. As $\beta$ varies, the shape of the oviposition curve changes, affecting the rate at which the probability of fly oviposition declines with increasing numbers of insects present in a flower head.

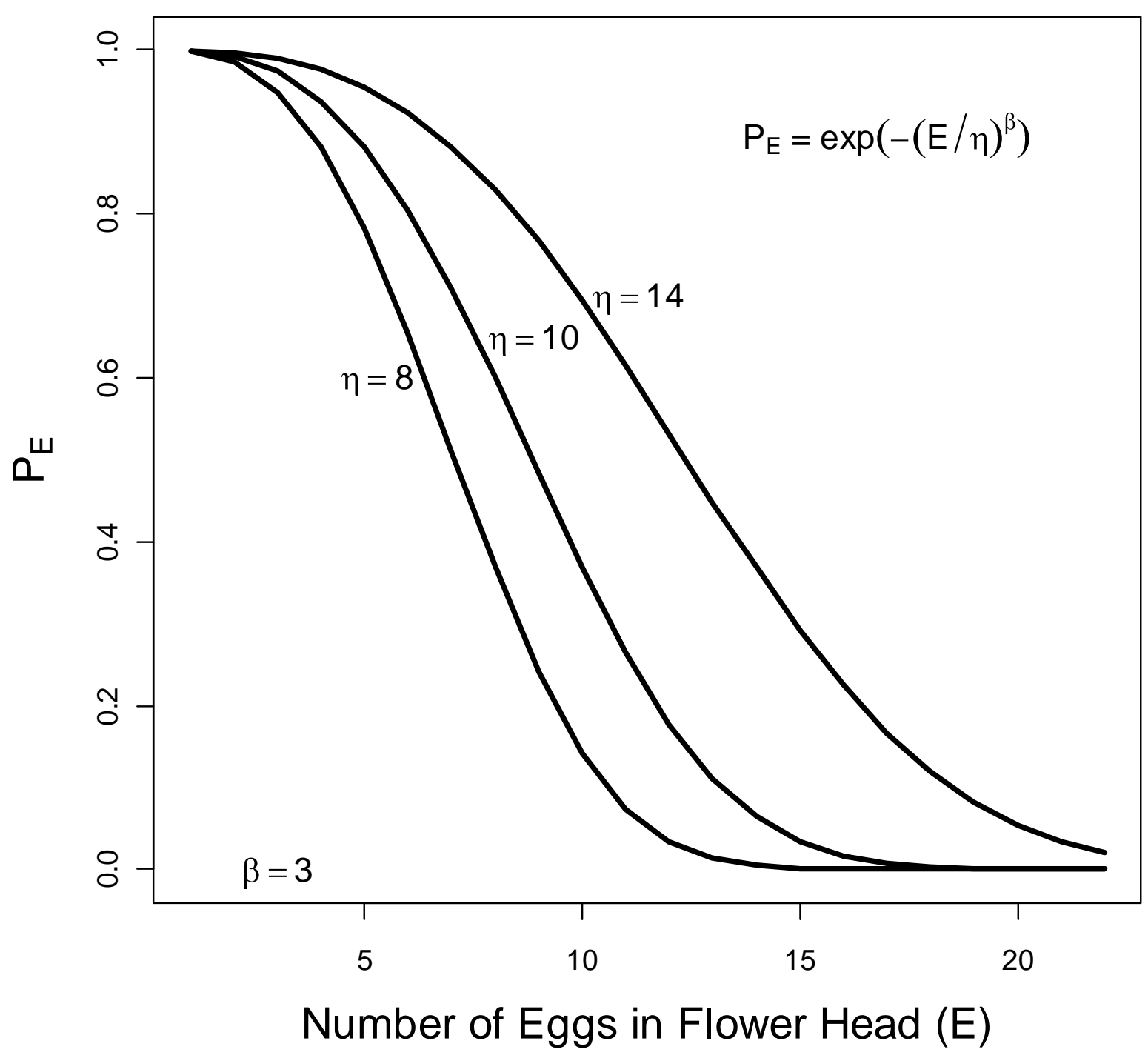


II. Effect of changes in the scale parameter ( $\eta$ ) on the oviposition probability. As $\eta$ increases the probability of ovipositing asymptotes to zero at higher E-values).

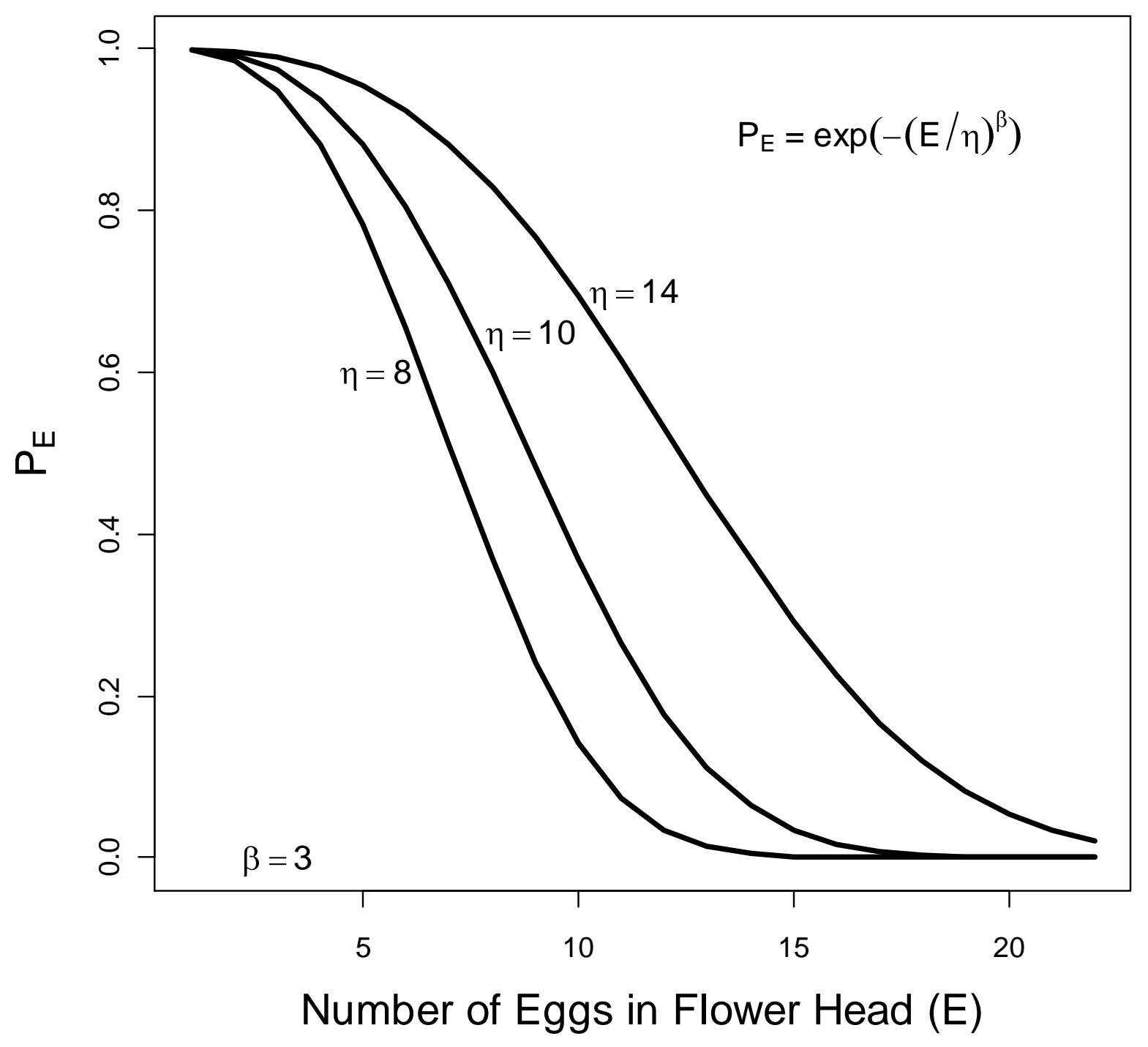

III. Effect of initial egg load of female flies on stochastic carrying capacity $\left(\mathrm{K}_{\mathrm{s}}\right)$ per 20 flower heads. We found that $\mathrm{K}_{\mathrm{s}}$ was not influenced by egg limitation in female flies, at any level of $R$. conicus infestation of flower heads. ( $\beta=3, \eta=10$, number of flower heads $=20$, priority strength $=9[\sim$ strength shown in the pre-oviposition experiment $])$. 


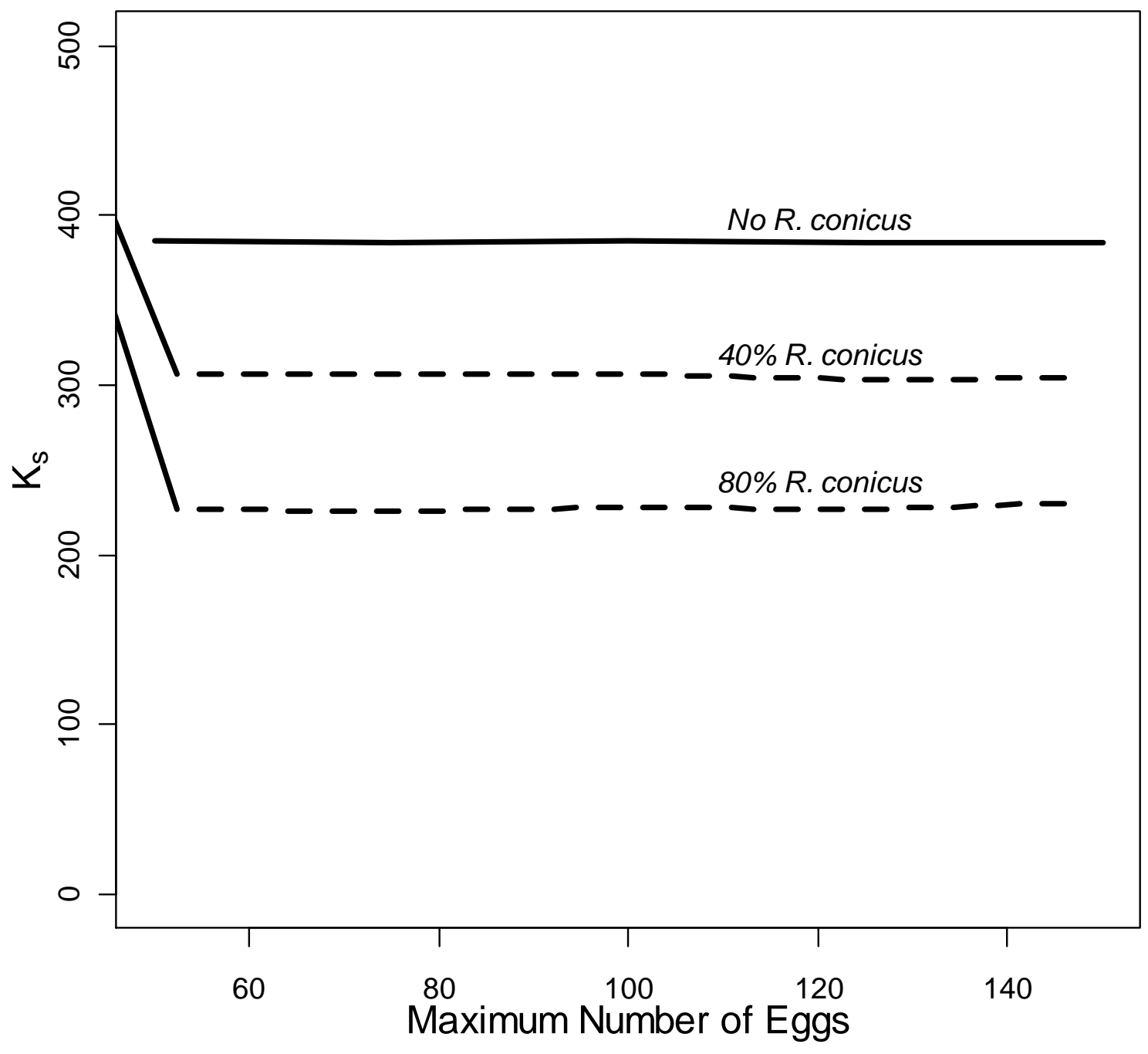


IV. Effect of the number of oviposition opportunities per female fly on the stochastic carrying capacity $\left(\mathrm{K}_{\mathrm{s}}\right)$ per 20 flower heads. We plotted the effect for three levels of $R$. conicus infestation of flower heads. $(\beta=3, \eta=10$, number of flower heads $=20$, priority strength $=9[\sim$ strength shown in the pre-oviposition experiment]).

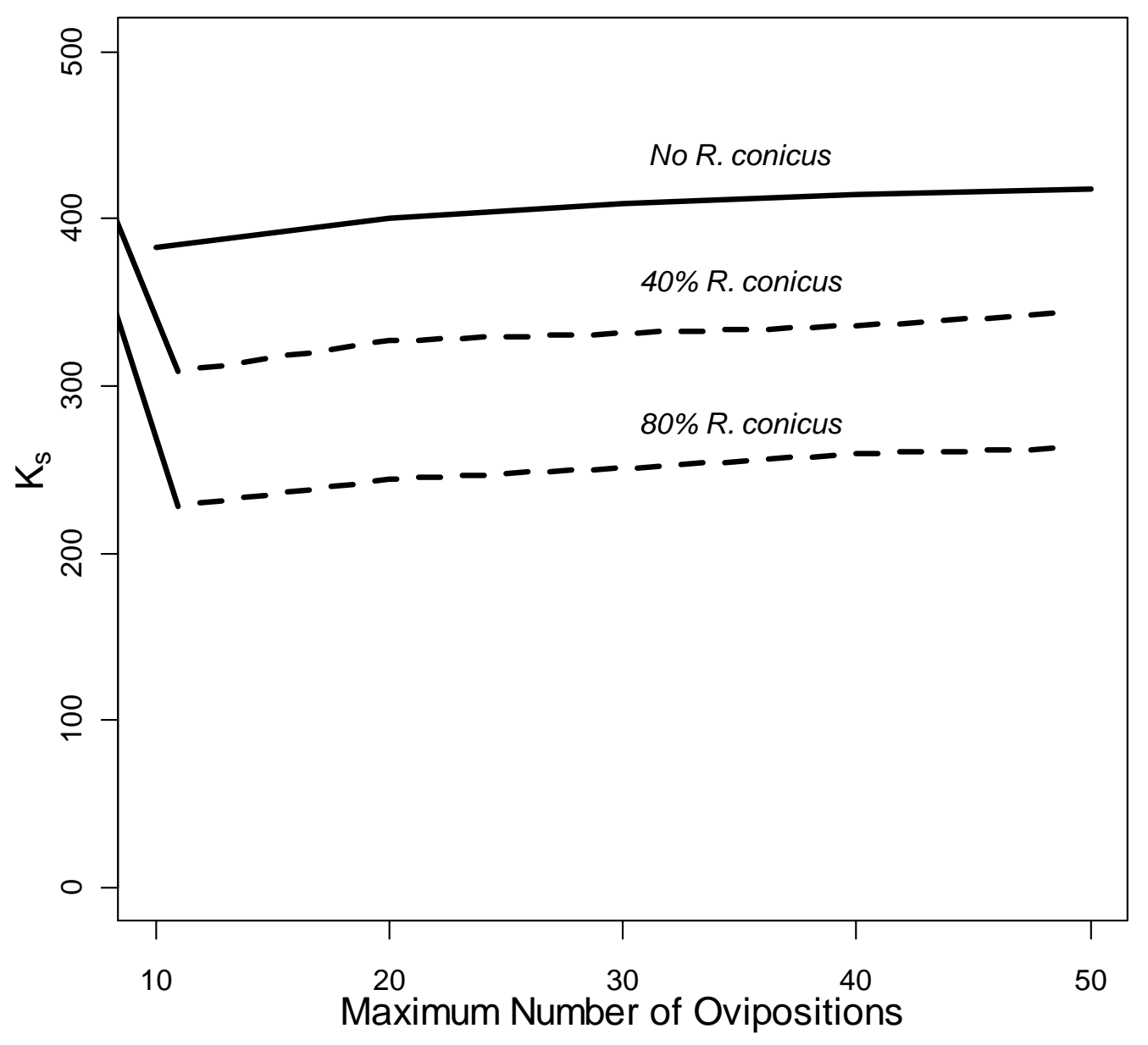

